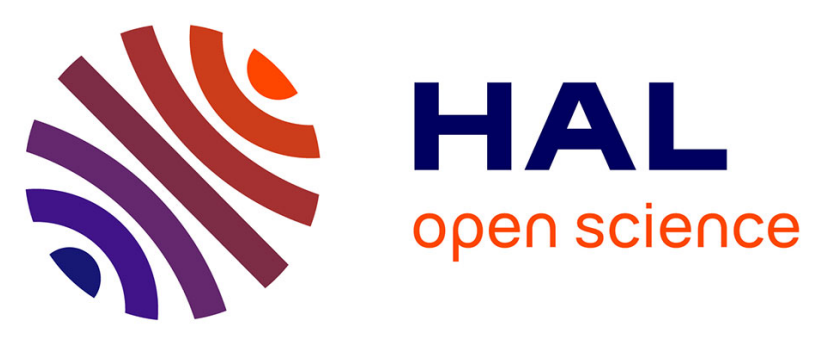

\title{
Effect of ammonium, electron donor and sulphate transient feeding conditions on sulphidogenesis in sequencing batch bioreactors
}

Luis Carlos Reyes-Alvarado, Frédéric Habouzit, Eldon R. Rene, Gaelle Santa-Catalina, Renaud Escudié, Nicolas Bernet, Piet N. L. Lens

\section{To cite this version:}

Luis Carlos Reyes-Alvarado, Frédéric Habouzit, Eldon R. Rene, Gaelle Santa-Catalina, Renaud Escudié, et al.. Effect of ammonium, electron donor and sulphate transient feeding conditions on sulphidogenesis in sequencing batch bioreactors. Bioresource Technology, 2019, 276, pp.288-299. 10.1016/j.biortech.2018.12.087 . hal-02623546

\section{HAL Id: hal-02623546 \\ https://hal.inrae.fr/hal-02623546}

Submitted on 26 May 2020

HAL is a multi-disciplinary open access archive for the deposit and dissemination of scientific research documents, whether they are published or not. The documents may come from teaching and research institutions in France or abroad, or from public or private research centers.
L'archive ouverte pluridisciplinaire HAL, est destinée au dépôt et à la diffusion de documents scientifiques de niveau recherche, publiés ou non, émanant des établissements d'enseignement et de recherche français ou étrangers, des laboratoires publics ou privés. 


\section{Accepted Manuscript}

Effect of ammonium, electron donor and sulphate transient feeding conditions on sulphidogenesis in sequencing batch bioreactors

Luis C. Reyes-Alvarado, Frédéric Habouzit, Eldon R. Rene, Gaëlle SantaCatalina, Renaud Escudie, Nicolas Bernet, Piet N.L. Lens

PII: S0960-8524(18)31758-9

DOI: https://doi.org/10.1016/j.biortech.2018.12.087

Reference: BITE 20844

To appear in:

Bioresource Technology

Received Date:

11 November 2018

Revised Date: 22 December 2018

Accepted Date: 24 December 2018

Please cite this article as: Reyes-Alvarado, L.C., Habouzit, F., Rene, E.R., Santa-Catalina, G., Escudie, R., Bernet, N., Lens, P.N.L., Effect of ammonium, electron donor and sulphate transient feeding conditions on sulphidogenesis in sequencing batch bioreactors, Bioresource Technology (2018), doi: https://doi.org/10.1016/j.biortech. 2018.12.087

This is a PDF file of an unedited manuscript that has been accepted for publication. As a service to our customers we are providing this early version of the manuscript. The manuscript will undergo copyediting, typesetting, and review of the resulting proof before it is published in its final form. Please note that during the production process errors may be discovered which could affect the content, and all legal disclaimers that apply to the journal pertain. 
Effect of ammonium, electron donor and sulphate transient feeding conditions on sulphidogenesis in sequencing batch bioreactors

Luis C. Reyes-Alvarado ${ }^{\mathrm{a}, \mathrm{b}}$, Frédéric Habouzit ${ }^{\mathrm{a}}$, Eldon R. Rene ${ }^{\mathrm{b},{ }^{*}}$, Gaëlle Santa-Catalina ${ }^{\mathrm{a}}$, Renaud Escudie $^{\mathrm{a}}$, Nicolas Bernet ${ }^{\mathrm{a}}$ and Piet N. L. Lens ${ }^{\mathrm{b}}$

${ }^{\text {a} I N R A, ~ U R 50, ~ L a b o r a t o i r e ~ d e ~ B i o t e c h n o l o g i e ~ d e ~ l ' E n v i r o n n e m e n t, ~ A v e n u e ~ d e s ~ E t a n g s, ~ N a r b o n n e ~}$ F-11100, France

${ }^{\mathrm{b}}$ UNESCO-IHE Institute for Water Education, P.O. Box 3015, 2601 DA Delft, The Netherlands

\section{*Corresponding author}

Eldon R. Rene

UNESCO-IHE Institute for Water Education,

P.O. Box 3015, 2601 DA Delft, The Netherlands

E-mail: e.raj@un-ihe.org

Tel: $+31-152151840$

Fax: $+31-152122921$ 


\begin{abstract}
This work aimed to study the effect of transient feeding conditions on sulphidogenesis in 8 sequencing batch bioreactors (SBR). SBR L1 and H1, operated under steady-state conditions were used as the control reactors, while four SBR were tested under transient feeding conditions, using moderate (L2 and L3, feast and famine: 2.5 and $\left.0 \mathrm{~g} \mathrm{SO}_{4}{ }^{2-} \cdot \mathrm{L}^{-1}\right)$ and high (H2 and H3, feast and famine: 15 and $\left.0 \mathrm{~g} \mathrm{SO}_{4}{ }^{2-} \cdot \mathrm{L}^{-1}\right)$ loads. The sulphate removal efficiency $(R E)$ was $\geq 90 \%$ in $\mathrm{SBR}$ L2, L3 and H1. The $\mathrm{NH}_{4}{ }^{+}$famine conditions resulted in a higher sulphate $R E(\geq 40 \% \mathrm{H} 3)$ compared to feast conditions $(\leq 20 \% \mathrm{H} 2)$. Besides, the sulphidogenic first-order kinetic constant was $4 \%$ larger and the use of electron donor was $16.6 \%$ more efficient under $\mathrm{NH}_{4}{ }^{+}$famine conditions. Sulphidogenesis is robust to transient feeding conditions, but not when applying high loading rates (SBR $\mathrm{H} 2$ and $\mathrm{H} 3)$.
\end{abstract}

Keywords: Sulphate reduction, sulphidogenesis, wastewater treatment, sequencing batch reactor, transient feeding conditions, feast-famine

\title{
1 Introduction
}

Sulphate rich wastewater is a serious environmental problem. Sulphate needs to be removed from industrial wastewater under controlled conditions. Adversely, if sulphate is reduced under uncontrolled conditions the corrosive sulphide can be produced (Reyes-Alvarado, 2018). Sulphate rich industrial wastewaters possess characteristics such as low $\mathrm{pH}$, high oxidative potential, can contain high concentrations of toxic metals and lack chemical oxygen demand (COD). Therefore, they can dramatically damage the flora and fauna of water reservoirs upon discharge without proper treatment (Mapanda et al., 2007).

Biotechnologically, sulphate reducing bacteria (SRB) reduce sulphate to sulphide by means of COD utilization at different stoichiometric relations (Liamleam and Annachhatre, 2007). Besides, SRB are capable to perform sulphate reduction using different electron donors, 
e.g. hydrogen, ethanol, glucose, propionate, butyrate, among other complex mixtures like molasses (Liamleam and Annachhatre, 2007). However, most SRB lack the enzymes required to perform the hydrolysis of complex polymers and, therefore they use soluble organic monomers (Liamleam and Annachhatre, 2007). Most recently, slow release electron donors, such as carbohydrate based or lignocellulosic polymers, have been used for the removal of sulphate in batch (Reyes-Alvarado et al., 2017b; Reyes-Alvarado, 2018) as well as in continuous (ReyesAlvarado et al., 2018a) bioreactors. Such slow release electron donors promise high sulphate $R E$ in batch. For instance, potato, filter paper and scourer showed $\geq 95 \%$ and cork $82 \%$ sulphate $R E$ (Reyes-Alvarado et al., 2017b, 2018a).

The removal of sulphate by SRB from sulphate rich wastewaters has been studied in different anaerobic reactors, i.e. batch reactor (Al-Zuhair et al., 2008), sequencing batch reactor (SBR) (Torner-Morales and Buitrón, 2010), up-flow anaerobic sludge blanket reactor (UASB) (Bertolino et al., 2012), extended granular sludge bed reactor (EGSB) (Dries et al., 1998), gas lift reactor (Sipma et al., 2007) and inverse fluidized bed bioreactors (IFBB) (Reyes-Alvarado et al., 2018b, 2017a). Among these studies, the effect of the COD:sulphate ratio and the HRT have been studied extensively for high sulphate removal efficiencies $(R E>75 \%)$. These different technologies offer diverse advantages in terms of biomass retention and, therefore, capacity of organic loading (Nicolella et al., 2000). SBR is a mature technology and tested for nutrient (C, N and P) removal from domestic wastewater (Cydzik-Kwiatkowska et al., 2014), this bioreactor configuration is well known for high biomass retention. Hence, the nutrient removal is affected by the solid retention time (SRT) and this SRT also allows to control biomass aggregation such as flocs and granules in the SBR (Cydzik-Kwiatkowska et al., 2014; Liao et al., 2006). TornerMorales and Buitrón (2010) tested the SBR for sulphate removal and, using a cycle length of $6 \mathrm{~h}$ and a COD:sulphate ratio of 2 and 6, and reported a sulphate $R E$ of 90 and $100 \%$, respectively. 
Bioprocesses including reactions mediated by bacteria produce new cells and structures (e.g. enzymes and exopolysaccharides), and use electron donors and acceptors as energy sources. During anaerobic reactor operation, approximately 5 to $15 \%$ of the total influent COD (100\%) is used for biomass formation (de Lemos Chernicharo, 2007). Thus, SRB consume nutrients (e.g. C, $\mathrm{N}, \mathrm{S}$ and $\mathrm{P}$ ) during the sulphidogenesis and the process can be hampered by lack of nutrients or if the conditions in the bioreactors (operated as batch sequential or continuous mode) are not optimal. For instance, SRB need COD to produce sulphide during sulphidogenesis. COD starving, transient feeding or limiting conditions might thus dramatically, reduce the sulphate $R E$ (Velasco et al., 2008). Only few studies have reported the effect of transient feeding conditions in sulphidogenic bioreactors (Janyasuthiwong et al., 2016; Papirio et al., 2013; Reyes-Alvarado et al., 2017a). For instance, Papirio et al. (2013) showed that sulphidogenic bioreactors completely fail when the influent $\mathrm{pH}$ is decreased from 7.0 to 3.0, but recover (sulphate $R E>95 \%$ ) when the influent $\mathrm{pH}$ is increased to 5.0. Janyasuthiwong et al. (2016) reported that a sulphidogenic bioreactor decreases more than $35 \%$ of its performance when the reactor $\mathrm{pH}$ was decreased from 7.0 to 5.0, the sulphate $R E$ dropped from $75 \%$ to less than $40 \%$. Reyes-Alvarado et al. (2017a) showed that sulphidogenesis in a continuous bioreactor was not hampered after ten consecutive feast (the electron donor and acceptor were increased to $2133 \mathrm{mg} . \mathrm{L}^{-1}$ of lactate and $1495 \mathrm{mg} . \mathrm{L}^{-1}$ of sulphate) and famine (the electron donor and acceptor were removed from the influent) cycles of operation. During the feast feeding, the sulphate $R E(67 \pm 15 \%)$ was comparable with the previous operation period IV ( $71 \pm 4 \%$ ) of the same continuous bioreactor and also comparable with the performance of the control bioreactor $(61 \pm 15 \%)$ (Reyes-Alvarado et al., 2017a).

This study does not advise to operate bioreactors under transient feeding conditions as a strategy to reduce the start-up phase of sulphidogenesis. There is, however, lack of information about the performance of biological sulphate reduction processes during intermittent or transient 
operation of bioreactors. Hence, this study aims to determine the robustness and resilience to changing conditions $\left(\mathrm{COD}, \mathrm{SO}_{4}{ }^{2-}\right.$ and $\mathrm{NH}_{4}{ }^{+}$) on the biological sulphate reduction in SBR. Hereby we report (i) the effect of the sulphate concentrations during the start-up of a sulphidogenic SBR using two different inoculum (a methanogenic anaerobic and a sulphidogenic sludge), (ii) the effect of the electron donor and acceptor at transient feeding conditions (feast to famine), (iii) the effect of the electron donor and acceptor transient feeding conditions at high concentrations and (iv) the effect of the presence and absence of nitrogen source $\left(\mathrm{NH}_{4}{ }^{+}\right)$during the sulphidogenesis in SBR and batch bioreactors.

\section{Material and methods}

\subsection{Synthetic wastewater}

In this study, the synthetic wastewater had the following composition (in mg. $\mathrm{L}^{-1}$ ): $\mathrm{NH}_{4} \mathrm{Cl}(300)$, $\mathrm{MgCl}_{2} \cdot 6 \mathrm{H}_{2} \mathrm{O}(120), \mathrm{KH}_{2} \mathrm{PO}_{4}(200), \mathrm{KCl}(250), \mathrm{CaCl}_{2} \cdot 2 \mathrm{H}_{2} \mathrm{O}$ (15), yeast extract (20) and $0.5 \mathrm{~mL}$ of a mixture of micronutrients. The micronutrients solution contained (in mg. $\mathrm{L}^{-1}$ ): $\mathrm{FeCl}_{2} \bullet 4 \mathrm{H}_{2} \mathrm{O}$ (1500), $\mathrm{MnCl}_{2} \bullet 4 \mathrm{H}_{2} \mathrm{O}$ (100), EDTA (500), $\mathrm{H}_{3} \mathrm{BO}_{3}$ (62), $\mathrm{ZnCl}_{2}$ (70), $\mathrm{NaMoO}_{4} \bullet 2 \mathrm{H}_{2} \mathrm{O}$ (36), $\mathrm{AlCl}_{3} \cdot 6 \mathrm{H}_{2} \mathrm{O}(40), \mathrm{NiCl}_{3} \cdot 6 \mathrm{H}_{2} \mathrm{O}(24), \mathrm{CoCl}_{2} \cdot 6 \mathrm{H}_{2} \mathrm{O}(70), \mathrm{CuCl}_{2} \cdot 2 \mathrm{H}_{2} \mathrm{O}$ (20) and $\mathrm{HCl} 36 \%$ (1 mL) (Villa-Gomez et al., 2012). Sodium lactate and sodium sulphate were used as the electron donor and acceptor, respectively. The source of nitrogen $\left(300 \mathrm{mg} \mathrm{NH}_{4} \mathrm{Cl} . \mathrm{L}^{-1}\right)$ was excluded from the preparation of the synthetic wastewater when it was required by the experiment. The $\mathrm{pH}$ of the influent synthetic wastewater was adjusted to 6.0 with $\mathrm{NaOH}(1 \mathrm{M})$ or $\mathrm{HCl}(1 \mathrm{M})$. All reagents used in this study were of analytical grade.

\subsection{Sequencing batch reactor set up}

Eight SBR were operated in this study, all made of glass with the same configuration but with different working volume: two of 6 L (SBR L (low) and H (high)) and six of 2 L (SBR L1-3 and 
SBR H1-3). The SBR comprised of the following components: influent tank, two peristaltic pumps (Masterflex L/S), effluent tank, heating system (water bath), stirring system, sampling port and timer. The reactors operated at 3 cycles of $8 \mathrm{~h}$ per day. The schedule of each cycle was: 2 minutes to discharge, two minutes of feeding, 3 hours of agitation starting from time zero and 5 hours of settling from 3 to $8 \mathrm{~h}$ of the cycle. For the SBR of $6 \mathrm{~L}$ (SBR L (low) and H (high)), $1 \mathrm{~L}$ of supernatant was removed and the same volume was fed, resulting in an influent liquid flow ( $\left.Q_{\text {in }}\right)$ of 3 L. $\mathrm{d}^{-1}$ or an HRT of 2 d. For the SBR of 2 L (SBR L1-3 and SBR H1-3), 0.33 L of supernatant was removed and the same volume was fed, resulting in an influent liquid flow $\left(\mathrm{Q}_{\text {in }}\right)$ of $1 \mathrm{~L} . \mathrm{d}^{-1}$ or an HRT of $2 \mathrm{~d}$. The stirring system consisted of an axle with two propels, and the speed was fixed at $120 \mathrm{rpm}$. The temperature was controlled at $30{ }^{\circ} \mathrm{C}$ with a water bath (Cole Parmer, Polystat 12112-00).

\subsection{Batch reactor set up}

Batch bioreactors were also used, operated and constructed as described elsewhere (ReyesAlvarado et al., 2018a). These batch bioreactors consisted of serum bottles with a capacity of $0.12 \mathrm{~L}$, these used butyl rubber stoppers and aluminium caps for sealing. Syringes with long needles were used for sampling the supernatant. This procedure was essential to maintain the desired anaerobic conditions. The batch bioreactors were incubated at $30{ }^{\circ} \mathrm{C}$ and were agitated at 120 rpm on an orbital shaker (New Brunswick Scientific Innova 2100 platform shaker,

\section{Eppendorf, USA).}

\subsection{Source of biomass}

A 6 L working volume SBR was inoculated with sulphate reducing biomass and used as a control reactor (L) (Figure 1A). SBR L was operated with a volatile suspended solid (VSS) concentration of $8.9( \pm 1.5){\mathrm{g} \mathrm{VSS} . \mathrm{L}^{-1} \text { and total suspended solid (TSS) concentration of } 14.1( \pm 1.7) \mathrm{g} \text { TSS.L }}^{-1}$. 
At steady performance, the biomass was divided and used to inoculate the smaller (2 L volume) three SBR (Figure 1B) and batch bioreactors (Figure 1D).

A second 6 L working volume SBR named H (Figure 1A, of 6 L volume) was inoculated with anaerobic sludge from a methanogenic process treating vinasse wastewater, this contained $\left.36.5( \pm 0.6){\mathrm{g} \mathrm{VSS} . \mathrm{L}^{-1} \text { and } 75.6( \pm 1) \mathrm{g} \mathrm{TSS.L}}^{-1}\right)$. SBR H was operated, at steady performance, with a concentration of $15.9( \pm 0.7) \mathrm{g} \mathrm{VSS} . \mathrm{L}^{-1}$ and $25.8( \pm 0.3) \mathrm{g}$ TSS.L ${ }^{-1}$. Subsequently, the biomass was divided and used to inoculate another three SBR (Figure 1C, H1, H2 and H3 with 2 L working volume each) with $2 \mathrm{~L}$ of liquor volume containing $15.9 \mathrm{~g} \mathrm{VSS.L}{ }^{-1}$ of sulphate reducing biomass. Both SBR ( $\mathrm{L}$ and $\mathrm{H})$ were operated at a constant COD:sulphate ratio of 2.4 until steady biological sulphate $R E$ was $\geq 90 \%$.

The biomass of SBR L was divided in two parts (Figure 1): 5.2 L was used to inoculate the other three smaller SBR (L1, L2 and L3, Figure 1B) and 0.8 L was used for experiments in batch bioreactors (Figure 1D). The volume of 5.2 L was completed till $6 \mathrm{~L}$ with synthetic wastewater (lacking electron donor and acceptor), mixed-up and divided in portions of $2 \mathrm{~L}$ containing $7.7 \mathrm{~g}$ VSS.L ${ }^{-1}$ as sulphate reducing biomass for the new SBR operated at low sulphate concentrations (SBR L1, L2 and L3). The volume liquor of $0.8 \mathrm{~L}$, from SBR L, was used to inoculate bench scale batch bioreactors (Figure 1D). Immediately after sampling, $0.040 \mathrm{~L}$ of the liquor was placed

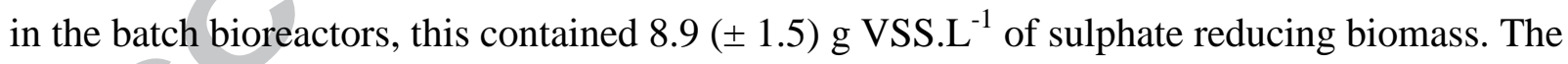
batch bottles were capped and, after two hours of settling, $0.030 \mathrm{~L}$ of supernatant was removed carefully with a syringe. This was followed by the addition of new synthetic wastewater with the desired electron donor (lactate), acceptor (sulphate) and $\mathrm{NH}_{4}{ }^{+}\left(\mathrm{NH}_{4} \mathrm{Cl}\right)$ concentrations. This procedure was essential to maintain the initial biomass concentration in the batch bioreactors constant. 


\subsection{Experimental design}

Two different biomass types were tested in two SBR, the control (L) and the experiment $(\mathrm{H})$ bioreactor (Figure 1A and Table 1). SBR L with sulphate reducing biomass was fed with $0.417 \mathrm{~g}$ $\mathrm{SO}_{4}{ }^{2-} \cdot \mathrm{L}^{-1}\left(140 \mathrm{mg} \mathrm{S}-\mathrm{SO}_{4}{ }^{2-} \cdot \mathrm{L}^{-1}\right)$ sulphate and $1 \mathrm{~g} \mathrm{COD} \cdot \mathrm{L}^{-1}$ lactate. SRB H was fed with sulphate at $2.5 \mathrm{~g} \mathrm{SO}_{4}{ }^{2-} \cdot \mathrm{L}^{-1}\left(840 \mathrm{mg} \mathrm{S}-\mathrm{SO}_{4}{ }^{2-} \cdot \mathrm{L}^{-1}\right)$ and $6 \mathrm{~g} \mathrm{COD} . \mathrm{L}^{-1}$ of lactate. In both SBR, the influent COD:sulphate ratio was maintained at 2.4. In SRB H, the sulphate and lactate concentrations were 6 times higher than those used for SBR L. SBR L was operated at an HRT of $2 \mathrm{~d}$ along the experiment. SBR $\mathrm{H}$ was operated under the following schedule: phase 1) initially, 8 days at $2 \mathrm{~d}$ HRT, phase 2) followed by 6 days of batch conditions, the influent and effluent pumps were stopped at this time, and phase 3) the last 20 days operated at $2 \mathrm{~d}$ HRT. Both SBR L and SBR H were operated at constant $\mathrm{NH}_{4}{ }^{+}$concentrations $\left(300 \mathrm{mg} \mathrm{NH}_{4} \mathrm{Cl}_{\mathrm{L}} \mathrm{L}^{-1}\right.$ ).

\subsection{Transient, feast-famine, feeding conditions in SBR operation}

Two SBR were used as control experiments, L1 and H1 (Figure 1B and C). SBR L1 was operated at low concentrations: $0.4 \mathrm{~g} \mathrm{SO}_{4}{ }^{2-} \cdot \mathrm{L}^{1}\left(140 \mathrm{mg} \mathrm{S}-\mathrm{SO}_{4}{ }^{2-} \cdot \mathrm{L}^{-1}\right)$ and $1 \mathrm{~g} \mathrm{COD}$ Lactate $\cdot \mathrm{L}^{-1}$. SBR $\mathrm{H} 1$ was operated at high concentrations: $2.5 \mathrm{~g} \mathrm{SO}_{4}{ }^{2-} \cdot \mathrm{L}^{-1}\left(840 \mathrm{mg} \mathrm{S}-\mathrm{SO}_{4}{ }^{2-} \cdot \mathrm{L}^{-1}\right)$ and $6 \mathrm{~g} \mathrm{COD}$ Lactate $\cdot \mathrm{L}^{-1}$. Neither the COD or sulphate concentrations nor the HRT were modified during the $22 \mathrm{~d}$ of SBR operation.

SBR L2 and L3 were operated at transient feeding conditions. Both reactors followed the schedule described in Figure 1E. The first four days, both SBR were operated at steady feeding conditions at $0.4 \mathrm{~g} \mathrm{SO}_{4}{ }^{2-} \cdot \mathrm{L}^{-1}\left(140 \mathrm{mg} \mathrm{S}-\mathrm{SO}_{4}{ }^{2-} \cdot \mathrm{L}^{-1}\right)$ and $1 \mathrm{~g} \mathrm{COD}_{\text {Lactate. }} \cdot \mathrm{L}^{-1}$, followed by a famine day. On a famine day, the influent pump was stopped and therefore any electron donor and acceptor were fed. The famine operation was followed by a feast day. During a feast day, $2.5 \mathrm{~g}$ $\mathrm{SO}_{4}{ }^{2-} \cdot \mathrm{L}^{-1}\left(840 \mathrm{mg} \mathrm{S}-\mathrm{SO}_{4}{ }^{2-} \cdot \mathrm{L}^{-1}\right)$ and $6 \mathrm{~g} \mathrm{COD}$ Lactate. $\mathrm{L}^{-1}$ were fed within the influent. 
SBR H2 and H3 were also operated at transient feeding conditions (Figure 1E) but at higher concentrations (compared to L2 and L3). The first four days, both SBR were operated at steady feeding conditions $\left(2.5 \mathrm{~g} \mathrm{SO}_{4}{ }^{2-} \cdot \mathrm{L}^{-1}\right.$ or $840 \mathrm{mg} \mathrm{S}-\mathrm{SO}_{4}{ }^{2-} . \mathrm{L}^{-1}$ and 6 g COD $\left.\mathrm{Lactate} \cdot \mathrm{L}^{-1}\right)$ and further followed by a famine day. The famine operation (described above) was followed by a feast day at $15 \mathrm{~g} \mathrm{SO}_{4}{ }^{2-} \cdot \mathrm{L}^{-1}\left(5000 \mathrm{mg} \mathrm{S}-\mathrm{SO}_{4}{ }^{2-} \cdot \mathrm{L}^{-1}\right)$ and $36 \mathrm{~g} \mathrm{COD}$ Lactate. $\mathrm{L}^{-1}$.

SBR L1 was operated at constant $\mathrm{NH}_{4}{ }^{+}$concentrations (300 $\left.\mathrm{mg} \mathrm{NH}_{4} \mathrm{Cl} . \mathrm{L}^{-1}\right)$ as well as SBR $\mathrm{H} 1\left(1800 \mathrm{mg} \mathrm{NH} 4 \mathrm{Cl} \cdot \mathrm{L}^{-1}\right)$. For SBR L2 and $\mathrm{H} 2$, the $\mathrm{NH}_{4}{ }^{+}$source $\left(\mathrm{NH}_{4} \mathrm{Cl}\right)$ was increased also 6 times (1800 mg NH 4 Cl.L $\mathrm{m}^{-1}$ ) during steady and transient (feast) feeding operation. $\mathrm{The}^{\mathrm{N}} \mathrm{H}_{4}^{+}$ source $\left(\mathrm{NH}_{4} \mathrm{Cl}\right)$ was only excluded $\left(0 \mathrm{mg} \mathrm{NH} \mathrm{Cl}_{4} \mathrm{~L}^{-1}\right)$ in $\mathrm{SBR} \mathrm{L} 3$ and $\mathrm{H} 3$ influent feeding, from the start of their operation. Concerning the electron donor and acceptor, during the feast days of SBR operation, the COD:sulphate ratios was maintained at 2.4. The presence and absence, induced by the feast or famine operation, of $\mathrm{COD}$, sulphate and $\mathrm{NH}_{4}{ }^{+}$in the influent was the sole disturbance applied to the different SBR, as specified above. The cycle length $(8 \mathrm{~h})$ and the feast (24 h) and famine (24 h) length periods were chosen based on background information from other SBR operations.

\subsection{Sulphate reduction experiments in batch}

The sulphate reducing activity of the biomass was investigated in batch under feast and famine conditions (Figure 1D). The feast and famine conditions were induced by altering the initial $\mathrm{NH}_{4}{ }^{+}$ and sulphate concentrations. The lactate concentration (1,000 mg COD. $\left.\mathrm{L}^{-1}\right)$ was kept constant while the initial sulphate concentrations were 417, 666 and $1491 \mathrm{mg} \mathrm{SO}_{4}{ }^{2-} \cdot \mathrm{L}^{-1}$, in the respective batch bioreactors (Table 2). The initial $\mathrm{NH}_{4}{ }^{+}$concentration was excluded $\left(0 \mathrm{mg} \mathrm{NH} \mathrm{Cl}_{4} \mathrm{~L}^{-1}\right.$, zero) for the experiments $\mathrm{A}, \mathrm{B}$, and $\mathrm{C}$, while $300 \mathrm{mg} \mathrm{NH}_{4} \mathrm{Cl} \cdot \mathrm{L}^{-1}$ was the concentration for experiments $\mathrm{A}^{*}, \mathrm{~B} *$ and $\mathrm{C}^{*}$. Table 2 shows an overview of the 6 different initial feast and famine conditions 
used to evaluate the sulphate reducing activity of the biomass. All batch experiments were performed in triplicate.

\subsection{Evaluation of SBR performance}

The activity in the reactor was evaluated in terms of the loading rates $(L R)$, removal rates $(R R)$, fraction $(f)$ of a component in the effluent and removal efficiencies $(R E)$. The robustness and resilience of the process were evaluated in terms of resistance and resistance index, according to the following equations (Eqs. 1-6):

$$
\begin{array}{lr}
L R=\frac{Q(A)}{V} & \text { Eq. } 1 \\
R R=\frac{Q(A-B)}{V} & \text { Eq. } 2 \\
f=\frac{(A-B)}{A} & \text { Eq. } 3 \\
R E=\left(\frac{(A-B)}{A}\right) \times 100 & \text { Eq. } 4 \\
\text { Resistance }=\frac{R E}{\Delta t} & \text { Eq. } 5 \\
\text { Resistance index }=\frac{\text { Resistance of reactor experiment }}{\text { Resistance of reactor control }} & \text { Eq. } 6
\end{array}
$$

The flow rate $(Q)$ of $3 \mathrm{~L} . \mathrm{d}^{-1}$ was equivalent to 3 cycles.d $\mathrm{d}^{-1}$ and was used for the SBR with $6 \mathrm{~L}$ working volume (SBR L and H). The SBR with 2 L working volume (L1, L2, L3, H1, H2 and H3) used a $Q$ of $1{\mathrm{~L} . \mathrm{d}^{-1}}^{-1}$ (equivalent to 3 cycles.d ${ }^{-1}$ ). The operational reactor volume $(V)$ of the SBR was expressed in L. The initial or influent concentration $(A)$ and the final or effluent concentration $(B)$ of any compound fed to the biomass was used for calculation, e.g. compounds like the initial $\mathrm{SO}_{4}{ }^{2-}$, sulphate sulphur $\left({\mathrm{S}-\mathrm{SO}_{4}}^{2-}\right)$, sulphide $\left(\mathrm{S}-\mathrm{S}^{2-}\right)$, lactate or COD concentrations. The concentration of all influent and effluent carbon compounds, responsible for the COD, e.g. lactate and volatile fatty acids, were expressed in COD equivalents (with units of mg COD.L ${ }^{-1}$ ) and fractions (dimensionless). The time difference $(\Delta t)$ was defined between the time of starting a 
new condition $\left(t_{N C}\right)$ and the time necessary to reach removal efficiencies $\geq 80 \%$ of any compound $\left(t_{R E \geq 80 \%}\right)$. The batch volumetric $\left(V_{r}\right)$ and specific $\left(S_{r}\right)$ removal rates were calculated using the Eq. 7 and Eq. 8 at the time of evaluation $\left(t_{e}\right)$ corresponding to the steepest slope and using the initial VSS concentration $\left(V S S_{t 0}\right)$. For estimating the $V_{r}$ of sulphate, the numerator of Eq. 7 was divided by the fraction of sulphur present in sulphate $(0.3333)$.

The yield of sulphate removed on the COD (total COD used) was calculated using Eq. 9. In this equation, the fraction of sulphate $\left(1-f_{\mathrm{S}-\mathrm{SO}} 42-\right)$ consumed at $t_{e}$ was multiplied by the initial sulphate concentration for the respective batch incubation and further divided by the COD concentration at the same $t_{e}$. In this study, the first order kinetic constant $\left(k_{1}\right)$ of sulphate removal was calculated from the slopes depicted by the plot of the $V r$ of sulphate against the initial sulphate concentration in the batch (Eq. 10). According to Schmidt et al. (1985), Eq. 10 is recommended for the kinetic evaluation of substrate consumption in non-supporting growth conditions. In the batch experiments, the cell growth was considered as zero or negligible due to the initial substrate (either lactate or sulphate) to biomass ratio. The standard deviation was calculated for all average values of data enclosed in a period of SBR operation (> 3 data points) and, also, for every batch experiment in triplicate.

$$
\begin{aligned}
& V_{r}=\frac{\left[1-\left(f_{A}\right)_{t_{e}}\right] \times(B)}{t_{e} \times\left(\frac{1 d}{24 h}\right)} \\
& \left.S_{r}=\frac{V_{r}}{V S S_{t_{0}}}\right) \\
& Y_{S O_{4}^{2-} / T C O D}=\frac{\left(1-f_{S-S O_{4}^{2-}}\right)_{t_{e}} \times S_{4}^{2-}}{\left(1-f_{T C O D}\right)_{t_{e}} \times T C O D_{t_{0}}} \\
& -\frac{d S}{d t}=k_{1} S
\end{aligned}
$$

\subsection{Analytical techniques}

The $\mathrm{pH}$ was measured off-line using a sulphide resistant electrode (Prosense, Oosterhout, The Netherlands). Sulphate and ammonium were analyzed by ion chromatography (DIONEX 100) 
using a conductivity detector (Mottet et al., 2014). The volatile fatty acids (VFA) concentrations (acetate, propionate, iso-butyrate, butyrate, iso-valerate and valerate) were measured using a gas chromatograph (GC-800 Fisons Instrument) equipped with a flame ionization detector (Mottet et al., 2014). Lactate was analyzed by high performance liquid chromatography (HPLC) using a Aminex HPX-87H [300 $\times 7.8 \mathrm{~mm}$ column (Biorad), $35^{\circ} \mathrm{C}$ and $0.4 \mathrm{~mL} \cdot \mathrm{min}^{-1}$ flow rate $]$ with an isocratic elution solution of $0.005 \mathrm{M} \mathrm{H}_{2} \mathrm{SO}_{4}$ and a refractometric detector (Waters $\mathrm{R} 410$ ) as reported in the literature (Quéméneur et al., 2012). The VSS, TSS and the sulphide or total dissolved sulphide (TDS, by the methylene blue method) were measured according to the procedures outlined in Standard Methods (APHA, 1999).

\section{Results and discussion}

\subsection{Sulphate reduction using enriched sulphate reducing biomass as inoculum at low sulphate concentrations}

SBR L was operated during 34 days, when the $\mathrm{S}-\mathrm{SO}_{4}{ }^{2-}-R R$ reached the value equal to the $\mathrm{S}-\mathrm{SO}_{4}{ }^{2-}$ $-L R$, the sulphate $R E$ was assumed to be $100 \%$ (Figure $2 \mathrm{~A}-\mathrm{D})$. During the first $12 \mathrm{~d}$ of operation, a sulphate $R E$ of $22( \pm 15) \%$ was observed. The time to reach $>80 \%$ of sulphate $R E\left(t_{R E \geq 80 \%)}\right.$ was after $12 \mathrm{~d}$ of SBR operation. After this time (12 d), SBR L was considered to be under steady performance (sulphate $R E=90( \pm 9) \%$ ) until the end of the operation (Figure 2A). Sulphide concentrations were as low as $27( \pm 21)$ and $60( \pm 25) \mathrm{mg} \mathrm{S}^{2-} . \mathrm{L}^{-1}$, respectively, during and after the first $12 \mathrm{~d}$ of operation. The sulphide production rates ranged between 13 and $30 \mathrm{mg} \mathrm{S} \mathrm{S}^{2-} \cdot \mathrm{L}^{-1} \mathrm{~d}^{-1}$, respectively (Figure 2A).

The lactate $R R$ or consumption rates were equivalent to $100 \% R E$ along SBR operation (34 d). Likewise, the total COD (TCOD) $R E$ was $99( \pm 3) \%$ during the $34 \mathrm{~d}$ of operation (Figure 2B). The presence of COD as VFA, alcohols or other analytes in the effluent was very punctual 
but at very low concentrations (Figure 2C). For instance, iso-butyrate $(f=1)$ was detected during the first two days of operation. Propionate $(f=1)$ was detected as the sole VFA at day 8 of operation. Propionate $(f=0.39)$ and acetate $(f=0.6)$ were detected at day 20 of operation (Figure 2C).

Furthermore, the effluent $\mathrm{pH}$ was $7.81( \pm 0.14)$ during the non-steady performance, the first $12 \mathrm{~d}$ of SRB operation, and later it was maintained at $7.75( \pm 0.29)$ until the end of the steady performance (Figure 2D). The substrate to biomass ratio $\left(\mathrm{SO}_{4}{ }^{2-}: \mathrm{VSS}\right)$ was 0.025 during the operation of SBR L. A summary of the performance of SBR L is shown in Table 1.

\subsection{Sulphate reduction using methanogenic anaerobic sludge as inoculum at high sulphate concentrations}

SBR H was operated in the three experimental phases during 34 days of semi-continuous operation (Figure $2 \mathrm{E}-\mathrm{H}$ ). At the beginning of the first phase, $\mathrm{SBR} \mathrm{H}$ showed high $\mathrm{SO}_{4}{ }^{2-}-R R$, in the range of $1,165-1,192 \mathrm{mg} \mathrm{SO}_{4}{ }^{2-} \cdot \mathrm{L}^{-1} \mathrm{~d}^{-1}\left(392-401 \mathrm{mg} \mathrm{S}-\mathrm{SO}_{4}{ }^{2-} \cdot \mathrm{L}^{-1} \mathrm{~d}^{-1}\right)$, corresponding to a sulphate $R E>90 \%$. This $R E$ is supported by the initial $\mathrm{SO}_{4}{ }^{2-}: \mathrm{VSS}$ ratio $(0.068)$ and, therefore, by the initial biomass concentration $\left(36.5 \mathrm{~g} \mathrm{VSS.L}{ }^{-1}\right)$. Nevertheless, the $\mathrm{S}_{-} \mathrm{SO}_{4}{ }^{2-}-R R$ reached an average $R E$ of $62( \pm 25) \%$ during phase I, suggesting the washout of bacteria with poor settling time (> $5 \mathrm{~h})$. An increase in the sulphide concentration $\left(148 \pm 97 \mathrm{mg} \mathrm{S}^{2-} \cdot \mathrm{L}^{-1}\right)$ was observed and the production rate was $74( \pm 48) \mathrm{mg} \mathrm{S}^{2-} \cdot \mathrm{L}^{-1} \mathrm{~d}^{-1}$ during phase I (Figure $2 \mathrm{E}$ ).

During phase II (from 8.3-14.3 d), the influent and effluent pumps were switched off and therefore SBR H was operated in batch mode. During this time, the sulphate $R R(20 \pm 17 \mathrm{mg}$ $\mathrm{SO}_{4}{ }^{2-} \cdot \mathrm{L}^{-1} \mathrm{~d}^{-1}$ or $\left.7 \pm 6 \mathrm{mg} \mathrm{S-SO}{ }_{4}{ }^{2-} \cdot \mathrm{L}^{-1} \mathrm{~d}^{-1}\right)$ and sulphide production rate $\left(54 \pm 6 \mathrm{mg} \mathrm{\textrm {S } ^ { 2 - }} \cdot \mathrm{L}^{-1} \mathrm{~d}^{-1}\right)$ decreased, but the sulphide concentration and the sulphate $R E$ reached $324( \pm 34) \mathrm{mg} \mathrm{S} \mathrm{S}^{2-} \cdot \mathrm{L}^{-1}$ and $95( \pm 4) \%$, respectively, in SBR H. After $14.3 \mathrm{~d}$, the influent and effluent pumps were switched 
on and the sulphate $R E$ dropped to $65( \pm 12) \%$, while a sulphide production rate of $142( \pm 55) \mathrm{mg}$ $\mathrm{S}^{2-} \cdot \mathrm{L}^{-1} \mathrm{~d}^{-1}$ was observed, corresponding to a sulphide concentration of $284( \pm 111) \% \mathrm{mg} \mathrm{S} \mathrm{S}^{2-} \cdot \mathrm{L}^{-1}$, at the beginning of phase III.

The performance from days 20 to 34 (phase III) reached a steady sulphate $R E$ of $96( \pm$ $10) \%$, corresponding to a sulphate $R R$ of $1,193( \pm 140) \mathrm{mg} \mathrm{SO}_{4}{ }^{2-} \cdot \mathrm{L}^{-1} \mathrm{~d}^{-1}$ (or $401 \pm 47 \mathrm{mg} \mathrm{S}^{-\mathrm{SO}_{4}}{ }^{2-}$ . $\left.\mathrm{L}^{-1} \mathrm{~d}^{-1}\right)$. The sulphide production rate was $201( \pm 46) \mathrm{mg} \mathrm{S} \mathrm{S}^{2-} \cdot \mathrm{L}^{-1} \mathrm{~d}^{-1}$ at the highest sulphide concentration observed $\left(440 \pm 41 \mathrm{mg} \mathrm{S}^{2-} \cdot \mathrm{L}^{-1}\right)$ in SBR H (Figure $\left.2 \mathrm{E}\right)$. The lactate $R R$ or consumption rate was also equivalent to $100 \% R E$ in SBR $\mathrm{H}$ along the operation time (34 d). Only after changing the operation regime, from batch to semi-continuous, from phase II to phase III, the lactate in the effluent corresponded to fraction $f=0.6$. This was the only time at which lactate was detected in the effluent. On the other hand, the TCOD $R R$ showed different performances during the three phases, corresponding to a TCOD $R E$ of $60( \pm 21) \%$ during phase I, $84( \pm 23) \%$ during phase II, $89( \pm 4) \%$ at the beginning of phase III and $90( \pm 7) \%$ during the steady performance of phase III (Figure $2 \mathrm{~F}$ ).

During the first 2 days of SBR H operation, acetate $(f=1)$ was the main effluent COD component. But suddenly, after 2 and until 8 days of operation, propionate $(f=0.6 \pm 0.27)$ was the dominant fraction followed by acetate $(f=0.4 \pm 0.27)$ during phase I. During phase II, propionate $(f=1)$ was the only VFA in the reactor after one day of batch operation. At the end of phase II, there was no VFA or any other analyte in the effluent. Lactate $(f=0.6)$ and acetate $(f=$ 0.39) were detected in the effluent after one day of operation of phase III. On day 20, propionate $(f=0.6)$ was observed as the main VFA followed by acetate $(f=0.4)$. After 20 days of operation, SBR H reached steady sulphate $R E(96 \pm 10 \%)$ performance and acetate $(f=0.8 \pm 0.2)$ was the major VFA followed by propionate $(f=0.2 \pm 0.2)$ (Figure $2 \mathrm{G})$. 
During the sulphate reduction process in SBR $\mathrm{H}$, the observed effluent $\mathrm{pH}$ was $>7.0$ and $<8.0$ for $34 \mathrm{~d}$ (Figure $2 \mathrm{H})$. The performance of SBR H is summarized in Table 1. During its steady performance, the VSS concentration was $15.9 \mathrm{~g} \mathrm{VSS.L}{ }^{-1}$ in SBR H and, therefore, the $\mathrm{SO}_{4}{ }^{2-}:$ VSS ratio was equal to 0.15 .

A fast sulphate removal by SBR L was expected due to the conditions tested: no COD limiting conditions, COD:sulphate ratio of 2.4 and sulphate:VSS ratio of 0.025 . However, 12 days were required to reach steady performance and a sulphate $R E=90( \pm 9) \%$. Al-Zuhair et al. (2008) found that the specific growth rate of pure cultures of SRB is increased by high sulphate concentrations, as high as $2.5 \mathrm{~g} \mathrm{SO}_{4}{ }^{2-} \cdot \mathrm{L}^{-1}$. There is evidence that SRB growth and activity is improved by increasing the sulphate concentrations also when anaerobic sludge is used as inoculum (O'Reilly and Colleran, 2006). Therefore, the sulphate reduction was higher in SBR H $(62 \pm 25 \%)$ starting from the first phase of operation, when it was exposed to higher initial sulphate concentrations $\left(2.5 \mathrm{~g} \mathrm{SO}_{4}{ }^{2-} \cdot \mathrm{L}^{-1}\right)$ (Figure 2E). In contrast, the control SBR L showed a poor sulphate $R E(22 \pm 15 \%)$ using $0.4 \mathrm{~g} \mathrm{SO}_{4}{ }^{2-} \cdot \mathrm{L}^{-1}$ during the first 12 days of operation (Figure 2A). This difference can be supported by the high bacterial diversity present in the anaerobic sludge (Guo et al., 2014), such diversity is beneficial for the robustness and resilience of a biological system.

SBR H was inoculated with anaerobic sludge and compared to an enriched sulphate reducing biomass present in SBR L. In both SBR L and SBR H, the lactate was used efficiently $(R E=100 \%)$ from the beginning of the experiment till the end (Figure 2B and F). SBR H showed a low COD $R E$ and $R R\left(60 \pm 21 \%\right.$ and $1,793 \pm 616 \mathrm{mg}$ COD. $\left.\mathrm{L}^{-1} \mathrm{~d}^{-1}\right)$ when compared to the control SBR L (COD $R E=99 \pm 3 \%$ and a COD $R R=495 \pm 14 \mathrm{mg}$ COD.L $\left.\mathrm{L}^{-1} \mathrm{~d}^{-1}\right)$. The propionate fraction became dominant in the effluent, compared to the acetate fraction, in the first phase and the beginning of the third phase of SRB H operation (Figure $2 \mathrm{G}$ ). This propionate accumulation 
was not observed during the performance of SBR L, propionate was detected as $f=1$ and $f=0.39$ at day 8 and 20 of operation, respectively (Figure 2C). This evolution in SRB H suggests that hydrolytic-fermentative bacteria can outcompete the SRB for the fermentation of lactate to propionate during its non-steady performance compared to SBR L which had a well stablished pathway of carbon utilization during sulphate reduction. Zhao et al. (2008) reported, for a sulphidogenic bioreactor, that lactate can be consumed by two different pathways: either directly used for sulphate reduction (e.g. Desulfovibrio spp.) or firstly fermented to propionate and ethanol e.g. Clostridium spp. and Bacteroides spp.) and secondly the fermented products can be used by SRB (e.g. Desulfobulbus spp. or Desulfovibrio spp.). For instance, the specific growth rates of hydrolytic-fermentative bacteria $\left(\mu_{V F A \text { mixture }}>1.2 \mathrm{~d}^{-1}\right)$ (Escudié et al., 2005) is larger compared to SRB (Desulfovibrio desulfuricans, $\mu_{\text {Lactate }} \sim 0.052 \mathrm{~d}^{-1}$ ) (Cooney et al., 1996) and methanogenic archaea $\left(\mu_{\text {Acetate }} \sim 0.15-0.55 \mathrm{~d}^{-1}\right)$ (O'Flaherty et al., 1998). This supports the pathway of fermentation of lactate and further utilization of the fermented products as electron donors for sulphate reduction. Furthermore, the conversion of lactate to propionate (Eq. 11) has a lower standard free energy change of biological formation $\left(\Delta \mathrm{G}^{01}=-54.9 \mathrm{~kJ}\right.$.reaction $\left.{ }^{-1}\right)$ in contrast to sulphate reduction using the initial electron donor (COD Lactate $)$ by means of Eq. $12(-160.1$ kJ.reaction $\left.{ }^{-1}\right)$ and unlikely by Eq. $13\left(-255.3 \mathrm{~kJ}\right.$ reaction $\left.^{-1}\right)$.

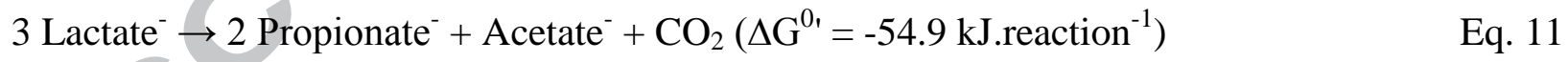
2 Lactate $^{-}+\mathrm{SO}_{4}{ }^{2-} \rightarrow 2$ Acetate $^{-}+\mathrm{HS}^{-}+2 \mathrm{HCO}_{3}{ }^{-}+\mathrm{H}^{+}\left(\Delta \mathrm{G}^{0 \prime}=-160.1\right.$ kJ.reaction $\left.{ }^{-1}\right) \quad$ Eq. 12

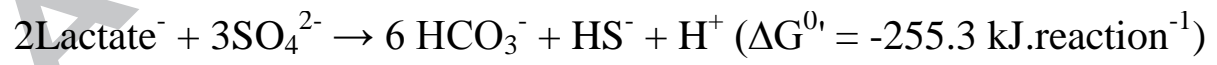

Eq. 12 describes sulphate reduction by SRB under no lactate limiting conditions and Eq. 13 suggests sulphate reduction by pure SRB species and avoid the competition for lactate by other microorganisms. However, Eq. 14 shows a $\Delta \mathrm{G}^{0{ }^{\prime}}=-37.7 \mathrm{~kJ}$. reaction ${ }^{-1}$ and suggests that sulphate reduction is also possible by means of propionate oxidation (Jr. Leslie Grady et al., 
2012). For instance, anaerobic sludge was reported to perform steady sulphate reduction at a $R E$ $=99.5 \%$ using a propionate:sulphate ratio of 1.31 (or a COD Propionate:sulphate ratio of 2.0), at an HRT of $2 \mathrm{~d}$ and an initial sulphate concentration of 1.97 g.L.-1 (Ghigliazza et al., 2000). The propionate:sulphate or $\mathrm{COD}_{\text {Propionate: }}$ sulphate ratios reported by Ghigliazza et al. (2000) are very much in agreement with the stoichiometry shown in Eq. (14):

Propionate ${ }^{-}+0.75 \mathrm{SO}_{4}{ }^{2-} \rightarrow$ Acetate $^{-}+\mathrm{HCO}_{3}{ }^{-}+0.75 \mathrm{HS}^{-}+0.25 \mathrm{H}^{+}$ $\left(\Delta \mathrm{G}^{0 \prime}=-37.7 \mathrm{~kJ} \cdot\right.$ reaction $\left.^{-1}\right)$

Eq. 14

High fractions of propionate in the effluent COD and low sulphate RE (e.g. $62 \pm 25 \%$ during phase I in SBR H) indicates a small population of propionate consuming SRB. On the other hand, low propionate fractions (as in SBR L) indicate a stable pathway of COD consumption during the sulphate reduction. Desulfobulbus like SRB are well known to utilize propionate as electron donor for sulphate reduction. Using conditions such as a COD:sulphate ratio of 2, Desulfobulbus like SRB accounted for $20 \%$ of the bacterial community (Dar et al., 2008). Therefore, when bacteria consumed the propionate, the sulphate $R E$ can be improved (i.e. to $95( \pm 4) \%$ in phase II) of SRB H and little or sporadic propionate formation was observed in the case of SRB L operation. During steady performance, the $\delta$-proteobacteria are the most abundant group rather than firmicutes during sulphate reduction using lactate as the electron donor (Zhao et al., 2010). Notwithstanding, the acetate fraction in the effluent is dominant during steady performance, despite acetotrophic sulphate reduction (Eq. 15): $\Delta \mathrm{G}^{0 \prime}$ of -48 kJ.reaction ${ }^{-1}$ and acetotrophic methanogenesis (Eq. 16): $\Delta \mathrm{G}^{0}$ of $-31.1 \mathrm{~kJ} \cdot$ reaction $^{-1}$.

$$
\begin{aligned}
& \text { Acetate }^{-}+\mathrm{SO}_{4}{ }^{2-} \rightarrow 2 \mathrm{HCO}_{3}{ }^{-}+\mathrm{HS}^{-}\left(\Delta \mathrm{G}^{0{ }^{\prime}}=-48 \mathrm{~kJ} \cdot \text { reaction }{ }^{-1}\right) \quad \text { Eq. } 15 \\
& \text { Acetate }^{-}+\mathrm{H}_{2} \mathrm{O} \rightarrow \mathrm{CH}_{4}+\mathrm{HCO}_{3}{ }^{-}\left(\Delta \mathrm{G}^{0 \prime}=-31.1 \text { kJ.reaction }{ }^{-1}\right) \quad \text { Eq. } 16
\end{aligned}
$$

Besides, SRB have a lower affinity $\left(>K_{S}\right.$ ) for acetate compared to acetotrophic methanogenic archaea $\left(<K_{S}\right)($ Stams et al., 2005), suggesting that acetate is removed by means of 
methanogenesis in both SBR L and $\mathrm{H}$, but at different rates. In contrast, at low COD:sulphate ratios $(<1.3), \mathrm{SRB}$ can outcompete methanogenic archae for acetotrophic sulphate reduction (Chou et al., 2008).

Changes on the operation mode of the bioreactors drive to improvements on the sulphate $R E$, e.g. changing from UASB to UASB with biomass recirculation operation (Boshoff et al., 2004). Increasing the HRT or SRT is beneficial for sulphate reduction, this change optimizes the contact time of bacteria (VSS) with the substrates. This suggest that slow growing SRB (in comparison to hydrolytic-fermentative bacteria) have the time to convert the propionate and overcome accumulation (e.g. in SBR H, Figure $2 \mathrm{G}$ ) or a shock load during transient operations. In this study, the influent pumps were switched off (in period II from day 8.3 to 14.3 ) to increase the HRT and the SRT in order to overcome the accumulation of propionate during the start-up of sulphidogenesis in SBR H.

High sulphide concentrations influence the sulphate reducing metabolism and can help to outcompete methanogenic archaea (Icgen and Harrison, 2006). When the HRT was decreased (from 2 days to 6 days of batch operation) to start period II in SBR H, the accumulation of sulphide $\left(324 \pm 34 \mathrm{mg} \mathrm{S} \mathrm{S}^{2-} \cdot \mathrm{L}^{-1}\right)$ supported the growth of the SRB population (Figure $2 \mathrm{E}$ ). Furthermore, Torner-Morales and Buitrón (2010) reported a decreasing sulphate $R E$ by $1 / 5$ and $1 / 2$ during the operation of SBR with sulphide stripping, the previous sulphate RE was 100 and 90\% for COD:sulphate ratios of 6 and 2, respectively. The SRB are more tolerant to high sulphide concentrations $\left(<1600 \mathrm{mg} \mathrm{S}^{2-} . \mathrm{L}^{-1}\right)$ than other bacteria and methanogenic archaea, the sulphide toxicity seems to be more specific or dependent for genus or groups (O'Flaherty et al., 1998). Continuous bioreactors, like the inverse fluidized bed bioreactors (IFBB), with biomass recirculation can operate at sulphide concentrations of $1,200 \mathrm{mg} \mathrm{S}^{2-} . \mathrm{L}^{-1}$ without affecting the 
COD or sulphate $R E$ (Celis-García et al., 2007). However, the toxicity due to high sulphide concentrations is higher when reactors are operated at long HRT (> 1 d) (Kaksonen et al., 2004).

A non-steady sulphate $R E$ was observed during the beginning of the third period of operation in SBR H, for $6 \mathrm{~d}$ (from 14 to $20 \mathrm{~d}$ of operation). Decreasing the HRT could have hampered the sulphate reducing process in SBR $\mathrm{H}$, the sulphate $R E$ was $65( \pm 12) \%$ and the COD $R E$ was $89( \pm 4) \%$ (Figure $2 \mathrm{E})$. After 20 days of SBR H operation, a steady sulphate $R E$ was achieved $(96 \pm 10 \%)$, wherein acetate was the major by-product and propionate became a minor component in the effluent COD $(\sim 10 \%$ of the COD fed). The steady sulphate reducing conditions imply a well-established metabolism in the presence of sulphate, this performance was reached in SBR L and $\mathrm{H}$ after 12 and $20 \mathrm{~d}$ of operation, respectively. However, the lack of propionate consuming SRB can hamper the performance of bioreactors (O'Flaherty and Colleran, 1999; Lens et al., 1998; Qauibi et al., 1990). During operation of SBR H, this was a key factor to reach the steady sulphate reducing performance, a drawback that was not observed during the operation of SBR L.

\subsection{Sulphate reduction under transient feeding conditions in the SBR}

SBR L1 (Figure 3A1-A3) showed a sulphate $R E$ of $79( \pm 17) \%$ and COD and lactate $R E$ of $100 \%$. VFA were not detected in the effluent (Figure 3A2) and the average $\mathrm{pH}$ was $7.4( \pm 0.2)$ (Figure 3A3). If the $\mathrm{S}-\mathrm{SO}_{4}{ }^{2-}-R R$ reached a value equal to the $\mathrm{S}_{-} \mathrm{SO}_{4}{ }^{2-}-L R$, the sulphate $R E$ was assumed to be $100 \%$. On the other hand, SBR H1 (Figure 4A1-A3) achieved a sulphate $R E$ of 94 $( \pm 8) \%$, lactate $R E$ of $99( \pm 3) \%$ and COD $R E$ of $93( \pm 7) \%$. Lactate $(f \leq 0.4)$ was present in the effluent on the first 2 days of operation. However, during the operation time, acetate and propionate became the only VFA dominant in the effluent COD (Figure 4A2), $0.58( \pm 25)$ and 
$0.38( \pm 0.24)$ were the respective average fractions. The average effluent $\mathrm{pH}$ was $7.7( \pm 0.2)$ (Figure 4A3).

SBR L2 performed sulphate removal under transient feeding conditions (feast: $6 \mathrm{~g}$ $\mathrm{COD}_{\text {Lactate. }} \mathrm{L}^{-1}$ and $2.5 \mathrm{~g} \mathrm{SO}_{4}{ }^{2-} \cdot \mathrm{L}^{-1}$ and famine: $0 \mathrm{~g} \mathrm{COD}$ Lactate. $\mathrm{L}^{-1}$ and $\left.0 \mathrm{~g} \mathrm{SO}_{4}{ }^{2-} \cdot \mathrm{L}^{-1}\right), 92( \pm 13) \%$ and $90( \pm 11) \%$, respectively, during feast and famine conditions (Figure 3B1). Lactate was always consumed at $100 \% R E$ and the COD $R E$ ranged between the feast $(99( \pm 1) \%)$ and famine $(92( \pm 6) \%)$ conditions (Figure 3B2). The average fractions of acetate $(0.28 \pm 0.32)$ and propionate $(0.31 \pm 0.34)$ were similar but the latter was in higher fractions after a feast day of operation. The $\mathrm{pH}$ was $7.7( \pm 0.1)$ during the feast and $7.5( \pm 0.1)$ during the famine conditions (Figure 3B3).

SBR H2 was fed with high concentrations of COD and sulphate $\left(36 \mathrm{~g} \mathrm{COD}_{\text {Lactate. }} \mathrm{L}^{-1}\right.$ and

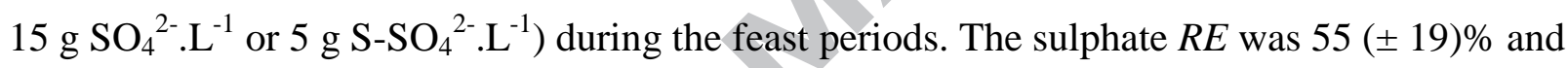
$36( \pm 29) \%$, respectively, during the feast and famine conditions, also this parameter decreased stepwise from $88 \%$ to $14 \%$ from 7 to 22 d of operation. The $\mathrm{S}_{-} \mathrm{SO}_{4}{ }^{2-} R R$ (Figure 4B1) and COD $R R$ decreased from, respectively, 2,224 mg S-SO ${ }_{4}{ }^{2-} \cdot \mathrm{L}^{-1} \mathrm{~d}^{-1}\left(6670 \mathrm{mg} \mathrm{SO}{ }_{4}{ }^{2-} \cdot \mathrm{L}^{-1} \mathrm{~d}^{-1}\right)$ and 15,174 mg COD. $\mathrm{L}^{-1} \mathrm{~d}^{-1}$ to $451 \mathrm{mg} \mathrm{S}-\mathrm{SO}_{4}{ }^{2-} \cdot \mathrm{L}^{-1} \mathrm{~d}^{-1}\left(1,347 \mathrm{mg} \mathrm{SO}{ }_{4}{ }^{2-} \cdot \mathrm{L}^{-1} \mathrm{~d}^{-1}\right)$ and $441 \mathrm{mg} \mathrm{COD} \cdot \mathrm{L}^{-1} \mathrm{~d}^{-1}$ at the end of the experiments. Lactate was only consumed partially, $85( \pm 8) \% R E$ during the feast and $86( \pm$ $14) \%$ during the famine conditions. The average COD $R E$ was $42( \pm 26) \%$ during the feast and $35( \pm 35) \%$ during the famine conditions. The average lactate fraction in the effluent was $0.2( \pm$ 0.2 ), but the rest of the effluent COD was composed by fractions as follows: acetate 0.43 ( \pm $0.29)$, propionate $0.30( \pm 0.23)$, butyrate $0.06( \pm 0.04)$ and iso-valerate $0.0022( \pm 0.0011)$. On the other hand, the lactate $R R$ recovered after the famine days: at the end of the experiment (20 to 22 d of operation), it was totally oxidized to VFA (Figure 4B2) and propionate $(f=0.61)$ was the dominant VFA effluent fraction followed by acetate $(f=0.28)$ and butyrate $(f=0.1)$. The average 
pH was $7.2( \pm 0.3)$ during the feast and $7.0( \pm 0.3)$ during the famine conditions, but the trend of the profile was decreasing until $\mathrm{pH}$ values $<7.0$ (Figure 4B3).

SBR L3 (Figure 3C1-C3) performed sulphate removal at transient feeing conditions (feast: $6 \mathrm{~g} \mathrm{COD}$ Lactate. $\mathrm{L}^{-1}$ and $2.5 \mathrm{~g} \mathrm{SO}_{4}{ }^{2-} \cdot \mathrm{L}^{-1}$ and famine: $0 \mathrm{~g} \mathrm{COD}$ Lactate. $\mathrm{L}^{-1}$ and $0 \mathrm{~g} \mathrm{SO}_{4}{ }^{2-} \cdot \mathrm{L}^{-1}$ ) in the absence of influent $\mathrm{NH}_{4}{ }^{+}$. The sulphate $R E$ was $92( \pm 11) \%$ during the feast and $86( \pm 11) \%$ during the famine conditions (Figure 3C1), while the average lactate $R E$ was $100 \%$ in the feast and $(99 \pm 4 \%)$ during the famine periods, only detected $(f=0.44)$ on day 20 . The COD $R E$ was higher $(96 \pm 3 \%)$ during the feast in comparison to famine $(85 \pm 8 \%)$ conditions (Figure $3 \mathrm{C} 2$ ). Acetate $(0.51 \pm 0.12)$ and propionate $(0.46 \pm 0.10)$ were the VFA fractions in the effluent, but propionate was with the higher fraction $(f=0.65)$ at the end of the operation. The $\mathrm{pH}$ was never below 7.0: it was $7.6( \pm 0.1)$ and $7.4( \pm 0.1)$, respectively, during the feast and famine conditions (Figure 3C3).

SBR H3 (Figure 4C1-C3) performed sulphate removal at transient feeding conditions, high concentrations of electron donor and acceptor $\left(36 \mathrm{~g} \mathrm{COD}\right.$ Lactate. $\mathrm{L}^{-1}$ and $15 \mathrm{~g} \mathrm{SO}_{4}{ }^{2-} \cdot \mathrm{L}^{-1}$ or $5 \mathrm{~g}$ $\left.\mathrm{S}-\mathrm{SO}_{4}{ }^{2-} \cdot \mathrm{L}^{-1}\right)$ and in the absence of $\mathrm{NH}_{4}{ }^{+}$. The sulphate $R E$ was $57( \pm 21) \%$ at feast and $55( \pm$ $28) \%$ at famine conditions, this parameter did not decrease to lower than $30 \%$ and it recovered from $\sim 30$ to $\sim 43 \%$ during the last two famine operation days (Figure 4C1). Also, the lactate $R E$ was very similar during the feast $(93 \pm 8 \%)$ and at famine $(92 \pm 10 \%)$ conditions and a fraction was left without consumption $(f=0.15$ to 0.47$)$. But the COD was not totally consumed, the $R E$ was $37( \pm 26) \%$ and $33( \pm 34) \%$ for the feast and famine conditions, respectively (Figure $4 \mathrm{C} 2)$. For instance, the effluent COD showed an average fraction composition of acetate $(0.45 \pm 0.19)$, propionate $(0.36 \pm 0.21)$, butyrate $(0.14 \pm 0.002)$, iso-butyrate $(0.003 \pm 0.001)$ and iso-valerate $(0.006 \pm 0.002)$. Nevertheless, propionate $(f=0.53)$ was the highest fraction followed by acetate $(f=0.44)$ in the effluent at the last 2 days of operation. During SBR H3 operation, the $\mathrm{pH}$ did not 
reach values $<7.0$; the average $\mathrm{pH}$ was $7.7( \pm 0.3)$ and $7.8( \pm 0.3)$, respectively, during the feast and famine conditions (Figure 4C3). In contrast, in SBR H2, the sulphate $R E$ decreased until $14 \%$ (Figure 4B1) and the $\mathrm{pH}$ was also $<7.0$ (Figure 4B3) at the last 2 days of operation.

The sulphate reduction process was not affected by the transient feeding conditions in SBR L2 and L3 (Figure 3B1 and C1). The performance in these bioreactors (the sulphate $R E$ was $\geq$ $90 \%$, unlike the sulphate $R E=86 \pm 11 \%$ whereas famine conditions in L3) was comparable to that of the control bioreactor at low concentrations (L1 sulphate $R E=79( \pm 17) \%$ ) and also at higher concentrations (H1 sulphate $R E=94 \pm 8 \%$ ). There are sulphidogenic bioreactors operating at sulphide concentrations of 1,215 mg.L $\mathrm{L}^{-1}$ without $\mathrm{H}_{2} \mathrm{~S}$ inhibition (Celis-García et al., 2007). However, the potential sulphide toxicity increases simultaneously to the increments of the HRT (Kaksonen et al., 2004). The maximum observed sulphide concentration was in the range of 818919 mg. $\mathrm{L}^{-1}$ for SBR H2 and H3.

The sulphate concentration of $2.5 \mathrm{~g} \mathrm{SO}_{4}{ }^{2-} \cdot \mathrm{L}^{-1}$ showed the optimal specific growth rate $\left(\mathrm{d}^{-}\right.$ ${ }^{1}$ ) using SRB pure cultures, in contrast, lower or higher concentrations can affect the SRB and the biochemical sulphate reduction activity (Al-Zuhair et al., 2008). Thus, the biological sulphate reduction was affected using higher concentrations of electron donor and acceptor (SBR H2 and H3: $36 \mathrm{~g} \mathrm{COD}$ Lactate. $\mathrm{L}^{-1}$ and $\left.15 \mathrm{~g} \mathrm{SO}_{4}{ }^{2-} \cdot \mathrm{L}^{-1}\right)$. The sulphate $R E$ was reduced to $<20 \%$ in $\mathrm{SBR} \mathrm{H} 2$ (Figure 4B1) and maintained slightly above 40\% in SBR H3 (Figure 4C1) until the end of the operation time.

The average lactate $R E$ was $\geq 99 \%$ in the control SBR (L1 and H1) and both SBR L2 and SBR L3 under feast and famine conditions. These SRB (L1, L2, L3, and H1) showed a COD RE $\geq 90 \%$, but SBR L3 showed a COD $R E$ of $85( \pm 8) \%$ during famine conditions. The average lactate $R E$ (92-93\%) was higher in SBR H3, regardless of the feast/famine conditions, when compared to SBR H2 (lactate $R E=85-86 \%$ ). The COD $R E$ dropped to very low values in SBR 
$\mathrm{H} 2(\sim 2 \%)$ as well as in SBR H3 $(\sim 6 \%)$ at the end of the reactor operation. The presence of propionate indicates that lactate was first consumed by hydrolytic-fermentative bacteria. Lactate can be degraded first by microorganisms other than SRB, such as the hydrolytic-fermentative or homoacetogenic bacteria (Dar et al., 2008; Wang et al., 2008). This evidenced that sulphate reduction was possible using lactate and also the propionate produced by hydrolytic-fermentative bacteria at the feast and famine conditions. However, sulphate reduction in the presence of acetate was less likely to occur. According to O'Reilly and Colleran (2006), at a COD:sulphate ratio $>2.1$, acetate is used by archaea for methanogenesis. Janyasuthiwong et al. (2016) showed that the sulphate reduction is inhibited in batch bioreactors when the acetate concentration is increased from 100 to $500 \mathrm{mg} . \mathrm{L}^{-1}$. This suggests that acetate needs to be removed by means of other processes, e.g. methanogenesis, rather than sulphate reduction when sulphate is present in wastewater; if acetate is not removed then the sulphate reduction will be inhibited. The acetate concentrations were very low in SBR L2 and L3 (Figure 3B2 and C2), when the COD RE was $\geq$ $90 \%$ and $85( \pm 8) \%$ (only in SBR L3 at famine conditions) at $6 \mathrm{~g} \mathrm{COD}$ Lactate. $\mathrm{L}^{-1}$ in the influent. On the other hand, SBR H2 and SBR H3 showed inhibition of the sulphate reduction because of the presence of high acetate concentrations (Figure 4 B2 and C2), this can be seen at very low COD RE (SBR H2 $\sim 2 \%$ and SBR H3 6\%) and high average acetate fractions (SBR H2 $f=0.38$ $( \pm 0.18)$ and SBR H3 $f=0.47( \pm 0.14))$ at $36 \mathrm{~g} \mathrm{COD}$ Lactate. $^{-1}$ in the influent.

The influent $\mathrm{pH}$ is a factor affecting the sulphate reduction in bioreactors. Papirio et al. (2013) observed that the sulphate reduction process fails when the influent $\mathrm{pH}$ is decreased from 7.0 to 3.0, but this recovered to a sulphate $R E$ of $97 \%$ when the $\mathrm{pH}$ was increased to an influent $\mathrm{pH}$ of 5.0. Janyasuthiwong et al. (2016) also observed that, when decreasing the influent $\mathrm{pH}$ from 7.0 to 5.0 , the sulphate $R E$ was reduced from $\sim 75 \%$ to $40 \%$. In this study, the influent $\mathrm{pH}$ was 6.0 in all the tested SBR, regardless whether steady or transient feeding conditions, while the 
average effluent $\mathrm{pH}$ was $>7.0$. Using lactate and propionate as electron donors, the biological sulphate reduction produces carbonate (Eq. 12-14), but SRB can also use other electron donors and produce carbonate (Liamleam and Annachhatre, 2007). The sulphidogenic process is responsible for the generation of the buffering capacity and achieving stable $\mathrm{pH}>7.0$ while sulphate rich wastewater treatment (Reyes-Alvarado et al., 2017a).

\subsection{Effect of $\mathrm{NH}_{4}{ }^{+}$famine conditions on sulphate reduction in bioreactors performance}

The experiments in batch using electron donor feast conditions (A and $\mathrm{A}^{*}, \mathrm{COD}$ :sulphate ratio of 2.4) showed different slopes during the sulphate removal process, but in the experiments A and $\mathrm{A}^{*}$, the sulphate removal fractions $(f)$ were, respectively, 0.96 and 0.98 within $8 \mathrm{~h}$ of operation (Table 2). The sulphate and lactate $V_{r}$ were $2,116 \mathrm{mg} \mathrm{SO}{ }_{4}^{2-} \cdot \mathrm{L}^{-1} \mathrm{~d}^{-1}$ and 5,526 mg COD $\mathrm{Lactate} \cdot \mathrm{L}^{-1} \mathrm{~d}^{-1}$ in the absence of $\mathrm{NH}_{4}{ }^{+}(\mathrm{A})$ and $1,834 \mathrm{mg} \mathrm{SO}_{4}{ }^{2-} \cdot \mathrm{L}^{-1} \mathrm{~d}^{-1}$ and 4,140 $\mathrm{mg} \mathrm{COD}$ Lactate. $\mathrm{L}^{-1} \mathrm{~d}^{-1}$ in the presence of $\mathrm{NH}_{4}^{+}\left(\mathrm{A}^{*}\right)$, respectively. Furthermore, the COD consumption $V_{r}$ was lower in comparison to that of lactate (COD), these were 3,448 mg COD.L $\mathrm{L}^{-1} \mathrm{~d}^{-1}$ for A and 2,240 mg COD. $\mathrm{L}^{-1} \mathrm{~d}^{-1}$ for $\mathrm{A}^{*}$.

The sulphate reduction, under feast conditions at a COD:sulphate ${ }^{-}$ratio of 1.5 , showed larger $V_{r}$ during the $\mathrm{NH}_{4}{ }^{+}$famine $\left(4,065 \mathrm{mg} \mathrm{SO}_{4}{ }^{2-} \cdot \mathrm{L}^{-1} \mathrm{~d}^{-1}, 6,697 \mathrm{mg} \mathrm{COD}\right.$ Lactate $\cdot \mathrm{L}^{-1} \mathrm{~d}^{-1}$ and 5,319 $\operatorname{mg}$ COD. $\left.\mathrm{L}^{-1} \mathrm{~d}^{-1}, \mathrm{~B}\right)$ in comparison to the $\mathrm{NH}_{4}{ }^{+}$feast $\left(3,488 \mathrm{mg} \mathrm{SO}{ }_{4}{ }^{2-} \cdot \mathrm{L}^{-1} \mathrm{~d}^{-1}, 4,920 \mathrm{mg}\right.$ COD Lactate. $^{-1} \mathrm{~d}^{-1}$ and 2,921 mg COD.L $\left.\mathrm{m}^{-1} \mathrm{~d}^{-1}, \mathrm{~B}^{*}\right)$ conditions in batch bioreactors. It is unlikely that the larger fraction of sulphate removed was at $\mathrm{NH}_{4}{ }^{+}$feast $\left(0.91\right.$ in $\left.\mathrm{B}^{*}\right)$ in comparison to the $\mathrm{NH}_{4}{ }^{+}$ famine $(0.78$ in $\mathrm{B})$ conditions within $24 \mathrm{~h}$ of operation (Table 2$)$.

The sulphate reduction, using electron donor famine conditions (COD: $\mathrm{SO}_{4}{ }^{2-}$ ratio of 0.67), showed the largest $V_{r}$ during the $\mathrm{NH}_{4}{ }^{+}$famine conditions $\left(9,673 \mathrm{mg} \mathrm{SO}{ }_{4}{ }^{2-} \cdot \mathrm{L}^{-1} \mathrm{~d}^{-1}, 7,033 \mathrm{mg}\right.$ COD Lactate $\mathrm{L}^{-1} \mathrm{~d}^{-1}$ and $5,715 \mathrm{mg}$ TCOD. $\left.\mathrm{L}^{-1} \mathrm{~d}^{-1}, \mathrm{C}\right)$ in comparison to the $\mathrm{NH}_{4}^{+}$feast conditions 
$\left(9,019 \mathrm{mg} \mathrm{SO}{ }_{4}^{2-} \cdot \mathrm{L}^{-1} \mathrm{~d}^{-1}, 5,703 \mathrm{mg} \mathrm{COD}\right.$ Lactate $\cdot \mathrm{L}^{-1} \mathrm{~d}^{-1}$ and 3,553 mg COD. $\left.\mathrm{L}^{-1} \mathrm{~d}^{-1}, \mathrm{C}^{*}\right)$ in batch reactors. The fractions of sulphate removed were very similar under the $\mathrm{NH}_{4}{ }^{+}$famine or feast conditions, 0.48 in $\mathrm{C}$ and 0.49 in $\mathrm{C}^{*}$, respectively, within $24 \mathrm{~h}$ of operation (Table 2).

Figure 5A shows the $V_{r}$ of sulphate removal increases but the fraction of sulphate removed decreases when the electron donor famine conditions increases The $k_{l}$ of sulphate removal was $4 \%$ lower using $\mathrm{NH}_{4}{ }^{+}$feast $\left(k_{1}=6.69 \mathrm{~d}^{-1}, r^{2}=1\right)$, compared to $\mathrm{NH}_{4}{ }^{+}$famine $\left(k_{l}=6.98\right.$ $\mathrm{d}^{-1}, r^{2}=0.9992$ ) conditions (Figure $5 \mathrm{~A}$ ). Under $\mathrm{NH}_{4}{ }^{+}$famine conditions, the $S_{r}$ by SRB used less electron donor (mg COD.mg VSS ${ }^{-1} \mathrm{~d}^{-1}$ ) for sulphate reduction (16.6\%) in comparison to the $\mathrm{NH}_{4}{ }^{+}$feast conditions (Figure 5B). The experiments under $\mathrm{NH}_{4}{ }^{+}$famine conditions are displaced to the left and top hand according to, respectively, the $\mathrm{X}$-axis and the $\mathrm{Y}$-axis in Figure 5B. This was also indicated on the slopes of the linear regression analysis using the $S_{r}$ data and the sulphate removed on the COD consumed: $4.39 \mathrm{mg}$ TCOD.mg VSS ${ }^{-1} \mathrm{~d}^{-1}$ under $\mathrm{NH}_{4}{ }^{+}$feast $\left(r^{2}=\right.$ $0.9895)$ and $3.66 \mathrm{mg}$ TCOD.mg VSS${ }^{-1} \mathrm{~d}^{-1}$ under $\mathrm{NH}_{4}{ }^{+}$famine $\left(r^{2}=0.99\right)$ conditions (Figure 5B).

In all the batch incubations, lactate and the COD were totally consumed, respectively, within $8 \mathrm{~h}$ and $24 \mathrm{~h}$ (Figure 5C and D). However, the lactate and COD $S_{r}$ were affected by the sulphate concentration or increasing electron donor famine conditions (Figure 5C and D). Acetate was the major VFA produced after $4 \mathrm{~h}$ of incubation, but it was also completely consumed within $24 \mathrm{~h}$. Propionate was produced $(f<0.1)$ after $4 \mathrm{~h}$ and consumed within $8 \mathrm{~h}$ in all batch reactor incubations, except for experiment $\mathrm{A}^{*}$ where propionate was consumed only after $8 \mathrm{~h}$.

Okabe et al. (1992) observed that Desulfovibrio desulfuricans decreased the electron donor uptake, the cell size was negatively affected and the carbon content of the cell decreased during sulphate reduction and $\mathrm{NH}_{4}{ }^{+}$famine conditions. During sulphidogenesis and sulphate feast conditions, Archaeoglobus fulgidus strain $Z$ developed higher biomass concentrations compared to sulphate starving conditions, also, the carbon uptake for biomass formation was larger at 
sulphate feast conditions (Habicht et al., 2005). Hence, the final sulphate removal was lower in SBR H2 ( $\leq 20 \%$ sulphate $R E, \mathrm{NH}_{4}{ }^{+}$feast conditions) compared to SBR H3 ( $\geq 40 \%$ sulphate $R E$, $\mathrm{NH}_{4}{ }^{+}$famine conditions). Under $\mathrm{NH}_{4}{ }^{+}$feast conditions, the $k_{l}$ of sulphate removal was $4 \%$ lower and the use of electron donor (mg COD.mg VSS${ }^{-1} \mathrm{~d}^{-1}$ ) was $16.6 \%$ larger for sulphate reduction; therefore, higher sulphate was removed in SBR H3. These differences were not observed between SBR L2 and SBR L3, because of the lower influent concentrations of electron donor and acceptor tested for sulphate reduction. This study showed that (i) influent sulphate concentrations of $2.5 \mathrm{~g}$ $\mathrm{SO}_{4}{ }^{2-} \cdot \mathrm{L}^{-1}$ reduced the start-up time of sulphidogenesis in the SBR and therefore higher sulphate $R R$ were observed, (ii) the sulphate reducing process is robust and resilience to transient feeding conditions even in low dynamic bioreactors as SBR and (iii) $\mathrm{NH}_{4}{ }^{+}$feast or famine conditions affect the kinetics of sulphate reduction in bioreactors. The COD:sulphate ratio is reported to be the most important parameter controlling the production of sulphide by means of dissimilatory sulphate reduction by SRB (Velasco et al., 2008). According to Torner-Morales and Buitrón (2010), a sulphate $R E>90 \%$ is guaranteed at a COD:sulphate ratio of 2.4 using lactate as electron donor. The COD:sulphate ratio of 2.4 was constant along the experiments, thus, this ratio was never modified for avoiding disturbances different than those of the transient feeding conditions in the respective SBR.

\section{Conclusions}

The sulphidogenic process is robust to transient feeding conditions. SBR L2 and SBR L3 reduced $\geq 90 \%$ of the supplied sulphate, similar to the control SBR H1 $(94 \pm 8 \%)$. The sulphate reduction was affected by the $\mathrm{NH}_{4}{ }^{+}$feast ( $R E$ dropped to $\leq 20 \%$ in SBR H2) or famine $(R E \geq 40 \%$ in SBR H3) conditions. Furthermore, the $k_{1}$ of sulphate removal under $\mathrm{NH}_{4}{ }^{+}$famine conditions, in the batch bioreactors, was $4 \%$ larger and the use of electron donor was $16.6 \%$ more efficient in comparison to $\mathrm{NH}_{4}{ }^{+}$feast conditions. 


\section{Supplementary information}

E-supplementary data of this work can be found in the online version of the paper.

\section{Acknowledgements}

This research was funded by the European Union through the Erasmus Mundus Joint Doctorate

Programme $\mathrm{ETeCoS}^{3}$ (Environmental Technologies for Contaminated Solids, Soils and

Sediments, grant agreement FPA no. 2010-0009). The authors thank the staff members from the

laboratory of INRA (Narbonne, France) for analytical assistance.

\section{References}

Al-Zuhair, S., El-Naas, M.H., Al-Hassani, H., 2008. Sulfate inhibition effect on sulfate reducing bacteria. J. Biochem. Technol. 1, 39-44.

Alon, U., Surette, M.G., Barkai, N., Leibler, S., 1999. Robustness in bacterial chemotaxis. Nature 397, 168-171. doi:10.1038/16483

APHA, 1999. Standard Methods for the Examination of Water and Wastewater, 20th ed. Washington, USA.

Bertolino, S.M., Rodrigues, I.C.B., Guerra-Sá, R., Aquino, S.F., Leão, V.A., 2012. Implications of volatile fatty acid profile on the metabolic pathway during continuous sulfate reduction. J. Environ. Manage. 103, 15-23, doi:10.1016/j.jenvman.2012.02.022

Boshoff, G., Duncan, J., Rose, P.., 2004. Tannery effluent as a carbon source for biological sulphate reduction. Water Res. 38, 2651-2658. doi:10.1016/j.watres.2004.03.030

Celis-García, L.B., Razo-Flores, E., Monroy, O., 2007. Performance of a down-flow fluidized bed reactor under sulfate reduction conditions using volatile fatty acids as electron donors. Biotechnol. Bioeng. 97, 771-779. doi:10.1002/bit.21288

Chou, H.-H., Huang, J.-S., Chen, W.-G., Ohara, R., 2008. Competitive reaction kinetics of sulfate-reducing bacteria and methanogenic bacteria in anaerobic filters. Bioresour. Technol. 99, 8061-8067. doi:10.1016/j.biortech.2008.03.044

Cooney, M.J., Roschi, E., Marison, I.W., Comninellis, C., von Stockar, U., 1996. Physiologic studies with the sulfate-reducing bacterium Desulfovibrio desulfuricans: evaluation for use in a biofuel cell. Enzyme Microb. Technol. 18, 358-65.

Cydzik-Kwiatkowska, A., Bernat, K., Zielińska, M., Wojnowska-Baryła, I., 2014. Cycle length 
and $\mathrm{COD} / \mathrm{N}$ ratio determine properties of aerobic granules treating high-nitrogen wastewater. Bioprocess Biosyst. Eng. 37, 1305-1313. doi:10.1007/s00449-013-1102-4

Dar, S.A., Kleerebezem, R., Stams, A.J.M., Kuenen, J.G., Muyzer, G., 2008. Competition and coexistence of sulfate-reducing bacteria, acetogens and methanogens in a lab-scale anaerobic bioreactor as affected by changing substrate to sulfate ratio. Appl. Microbiol. Biotechnol. 78, 1045-1055. doi:10.1007/s00253-008-1391-8

de Lemos Chernicharo, C.A., 2007. Biological Wastewater Treatment Vol.4: Anaerobic Reactors, 1st ed, Biological wastewater treatment in warm climate regions. IWA Publishing, London, UK.

Dries, J., De Smul, A., Goethals, L., Grootaerd, H., Verstraete, W., 1998. High rate biological treatment of sulfate-rich wastewater in an acetate-fed EGSB reactor. Biodegradation 9, 103111. doi:10.1023/A:1008334219332

Escudié, R., Conte, T., Steyer, J.P., Delgenès, J.P., 2005. Hydrodynamic and biokinetic models of an anaerobic fixed-bed reactor. Process Biochem. 40, 2311-2323.

doi:10.1016/j.procbio.2004.09.004

Ghigliazza, R., Lodi, A., Rovatti, M., 2000. Kinetic and process considerations on biological reduction of soluble and scarcely soluble sulfates. Resour. Conserv. Recycl. 29, 181-194. doi:10.1016/S0921-3449(99)00055-5

Guo, X., Wang, C., Sun, F., Zhu, W., Wu, W., 2014. A comparison of microbial characteristics between the thermophilic and mesophilic anaerobic digesters exposed to elevated food waste loadings. Bioresour. Technol. 152, 420-428. doi:10.1016/j.biortech.2013.11.012

Habicht, K.S., Salling, L., Thamdrup, B., Canfield, D.E., 2005. Effect of low sulfate concentrations on lactate oxidation and isotope fractionation during sulfate reduction by Archaeoglobus fulgidus strain Z. Appl. Environ. Microbiol. 71, 3770-3777. doi:10.1128/AEM.71.7.3770-3777.2005

Icgen, B., Harrison, S., 2006. Exposure to sulfide causes populations shifts in sulfate-reducing consortia. Res. Microbiol. 157, 784-791. doi:10.1016/j.resmic.2006.04.004

Janyasuthiwong, S., Rene, E.R., Esposito, G., Lens, P.N.L., 2016. Effect of pH on the performance of sulfate and thiosulfate-fed sulfate reducing inverse fluidized bed reactors. J. Environ. Eng. 142, 1-11. doi:10.1061/(ASCE)EE.1943-7870.0001004

Jr. Leslie Grady, C.P., Daigger, G.T., Love, N.G., M. Filipe, C.D., 2012. Stoichiometry and 
kinetics of aerobic/anoxic biochemical operations, in: Biological Wastewater Treatment. CRC Press, Taylor \& Francis Group, Boca Raton, FL. USA, pp. 75-127.

Kaksonen, A.H., Franzmann, P.D., Puhakka, J.A., 2004. Effects of hydraulic retention time and sulfide toxicity on ethanol and acetate oxidation in sulfate-reducing metal-precipitating fluidized-bed reactor. Biotechnol. Bioeng. 86, 332-343. doi:10.1002/bit.20061

Lens, P.N., Dijkema, C., Stams, A.J., 1998. 13C-NMR study of propionate metabolism by sludges from bioreactors treating sulfate and sulfide rich wastewater. Biodegradation 9, 179-186. doi:10.1023/A:1008395724938

Liamleam, W., Annachhatre, A.P., 2007. Electron donors for biological sulfate reduction. Biotechnol. Adv. 25, 452-463. doi:10.1016/j.biotechadv.2007.05.002

Liao, B.Q., Droppo, I.G., Leppard, G.G., Liss, S.N., 2006. Effect of solids retention time on structure and characteristics of sludge flocs in sequencing batch reactors. Water Res. 40, 2583-2591. doi:10.1016/j.watres.2006.04.043

Mapanda, F., Nyamadzawo, G., Nyamangara, J., Wuta, M., 2007. Effects of discharging acidmine drainage into evaporation ponds lined with clay on chemical quality of the surrounding soil and water. Phys. Chem. Earth, Parts A/B/C 32, 1366-1375. doi:10.1016/j.pce.2007.07.041

Mottet, A., Habouzit, F., Steyer, J.P., 2014. Anaerobic digestion of marine microalgae in different salinity levels. Bioresour. Technol. 158, 300-306. doi:10.1016/j.biortech.2014.02.055

Nicolella, C., van Loosdrecht, M.C., Heijnen, J.J., 2000. Wastewater treatment with particulate biofilm reactors. J. Biotechnol. 80, 1-33. doi:10.1016/S0168-1656(00)00229-7

O'Flaherty, V., Colleran, E., 1999. Effect of sulphate addition on volatile fatty acid and ethanol degradation in an anaerobic hybrid reactor. I: Process disturbance and remediation. Bioresour. Technol. 68, 101-107. doi:10.1016/S0960-8524(98)00145-X

O’Flaherty, V., Lens, P., Leahy, B., Colleran, E., 1998. Long-term competition between sulphatereducing and methane-producing bacteria during full-scale anaerobic treatment of citric acid production wastewater. Water Res. 32, 815-825. doi:10.1016/S0043-1354(97)00270-4

O'Flaherty, V., Mahony, T., O’Kennedy, R., Colleran, E., 1998. Effect of pH on growth kinetics and sulphide toxicity thresholds of a range of methanogenic, syntrophic and sulphatereducing bacteria. Process Biochem. 33, 555-569. doi:10.1016/S0032-9592(98)00018-1 
O'Reilly, C., Colleran, E., 2006. Effect of influent $\mathrm{COD} / \mathrm{SO}_{4}{ }^{2-}$ ratios on mesophilic anaerobic reactor biomass populations: physico-chemical and microbiological properties. FEMS Microbiol. Ecol. 56, 141-153. doi:10.1111/j.1574-6941.2006.00066.x

Okabe, S., Nielsen, P.H., Charcklis, W.G., 1992. Factors affecting microbial sulfate reduction by Desulfovibrio desulfuricans in continuous culture: limiting nutrients and sulfide concentration. Biotechnol. Bioeng. 40, 725-734. doi:10.1002/bit.260400612

Papirio, S., Esposito, G., Pirozzi, F., 2013. Biological inverse fluidized-bed reactors for the treatment of low $\mathrm{pH}$ - and sulphate-containing wastewaters under different COD conditions. Environ. Technol. 34, 1141-1149. doi:10.1080/09593330.2012.737864

Qatibi, A.I., Bories, A., Garcia, J.L., 1990. Effects of sulfate on lactate and C2-, C3- volatile fatty acid anaerobic degradation by a mixed microbial culture. Antonie Van Leeuwenhoek 58, $241-8$.

Quéméneur, M., Bittel, M., Trably, E., Dumas, C., Fourage, L., Ravot, G., Steyer, J.-P., Carrère, H., 2012. Effect of enzyme addition on fermentative hydrogen production from wheat straw. Int. J. Hydrogen Energy 37, 10639-10647. doi:10.1016/j.ijhydene.2012.04.083

Reyes-Alvarado, L.C. 2018. Optimization of the Electron Donor Supply to Sulphate Reducing Bioreactors Treating Inorganic Wastewater. ${ }^{\text {st }}$ Ed., CRC Press, Leiden, The Netherlands, pp: $1-234$.

Reyes-Alvarado, L.C., Camarillo-Gamboa, Á., Rustrian, E., Rene, E.R., Esposito, G., Lens, P.N.L., Houbron, E., 2018a. Lignocellulosic biowastes as carrier material and slow release electron donor for sulphidogenesis of wastewater in an inverse fluidized bed bioreactor.

Environ. Sci. Pollut. Res. 25, 5115-5128. doi:10.1007/s11356-017-9334-5

Reyes-Alvarado, L.C., Hatzikioseyian, A., Rene, E.R., Houbron, E., Rustrian, E., Esposito, G., Lens, P.N.L., 2018b. Hydrodynamics and mathematical modelling in a low HRT inverse fluidized-bed reactor for biological sulphate reduction. Bioprocess Biosyst. Eng. 41, 18691882. doi:10.1007/s00449-018-2008-y

Reyes-Alvarado, L.C., Okpalanze, N.N., Kankanala, D., Rene, E.R., Esposito, G., Lens, P.N.L., 2017a. Forecasting the effect of feast and famine conditions on biological sulphate reduction in an anaerobic inverse fluidized bed reactor using artificial neural networks. Process

Biochem. 55, 146-161. doi:10.1016/j.procbio.2017.01.021

Reyes-Alvarado, L.C., Okpalanze, N.N., Rene, E.R., Rustrian, E., Houbron, E., Esposito, G., 
Lens, P.N.L., 2017b. Carbohydrate based polymeric materials as slow release electron donors for sulphate removal from wastewater. J. Environ. Manage. 200, 407-415. doi:10.1016/j.jenvman.2017.05.074

Schmidt, S.K., Simkins, S., Alexander, M., 1985. Models for the kinetics of biodegradation of organic compounds not supporting growth. Appl. Environ. Microbiol. 50, 323-31.

Sipma, J., Osuna, M.B., Lettinga, G., Stams, A.J.M., Lens, P.N.L., 2007. Effect of hydraulic retention time on sulfate reduction in a carbon monoxide fed thermophilic gas lift reactor. Water Res. 41, 1995-2003. doi:10.1016/j.watres.2007.01.030

Stams, A.J.M., Plugge, C.M., de Bok, F.A.M., van Houten, B.H.G.W., Lens, P., Dijkman, H., Weijma, J., 2005. Metabolic interactions in methanogenic and sulfate-reducing bioreactors. Water Sci. Technol. 52, 13-20.

Torner-Morales, F.J., Buitrón, G., 2010. Kinetic characterization and modeling simplification of an anaerobic sulfate reducing batch process. J. Chem. Technol. Biotechnol. 85, 453-459. doi: $10.1002 /$ jetb. 2310

Velasco, A., Ramírez, M., Volke-Sepúlveda, T., González-Sánchez, A., Revah, S., 2008. Evaluation of feed COD/sulfate ratio as a control criterion for the biological hydrogen sulfide production and lead precipitation. J. Hazard. Mater. 151, 407-413. doi:10.1016/j.jhazmat.2007.06.004

Villa-Gomez, D.K., Papirio, S., van Hullebusch, E.D., Farges, F., Nikitenko, S., Kramer, H., Lens, P.N.L., 2012. Influence of sulfide concentration and macronutrients on the characteristics of metal precipitates relevant to metal recovery in bioreactors. Bioresour. Technol. 110, 26-34. doi:10.1016/j.biortech.2012.01.041

Wang, A., Ren, N., Wang, X., Lee, D., 2008. Enhanced sulfate reduction with acidogenic sulfatereducing bacteria. J. Hazard. Mater. 154, 1060-1065. doi:10.1016/j.jhazmat.2007.11.022 Zhao, Y.-G., Wang, A.-J., Ren, N.-Q., 2010. Effect of carbon sources on sulfidogenic bacterial communities during the starting-up of acidogenic sulfate-reducing bioreactors. Bioresour. Technol. 101, 2952-2959. doi:10.1016/j.biortech.2009.11.098

Zhao, Y., Ren, N., Wang, A., 2008. Contributions of fermentative acidogenic bacteria and sulfate-reducing bacteria to lactate degradation and sulfate reduction. Chemosphere 72, 233242. doi:10.1016/j.chemosphere.2008.01.046 


\section{List of figure captions}

Figure 1. The pathway of using biomass during the experiments. A) SBR L (left) and SBR H (right), B) SBR operated under low concentration of electron donor and acceptor (R1L, R2L and R3L), C) SBR operated under high concentrations of electron donor and acceptor (R1H, R2H and $\mathrm{R} 3 \mathrm{H}), \mathrm{D})$ Batch test and conditions for $\mathrm{NH}_{4}{ }^{+}$famine $(\mathrm{A}, \mathrm{B}$ and $\mathrm{C})$ and feast $\left(\mathrm{A}^{*}, \mathrm{~B}^{*}\right.$ and $\left.\mathrm{C}^{*}\right)$, and E) Schedule of feast and famine conditions in SBR. The parameter under steady and feast conditions are described inside the boxes. The famine conditions are not included in the boxes, but this refers to switching off the influent and effluent pumps

Figure 2. Performance of the SBR L (A-D) and SBR H (E-H). A) and E) Sulphur profiles: S-

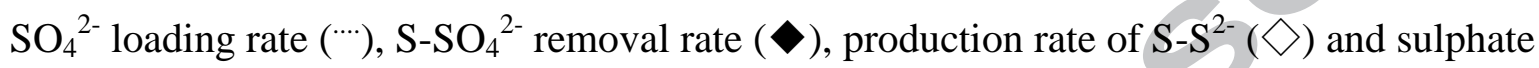
removal efficiency $(\times)$. B) and F) COD profiles: the COD loading rate ( $\left.{ }^{*}\right)$, COD removal rate $(\diamond)$, the lactate removal rate $(\bullet)$ and COD removal efficiency $(x) . C)$ and G) the fraction composition of the effluent COD: lactate $(\Delta)$, acetate $(\circ)$, propionate $(+)$ and iso-butirate $(*)$; D) and $\mathrm{H}) \mathrm{pH}$ profiles: the $\mathrm{S}_{-} \mathrm{SO}_{4}{ }^{2-}$ loading rate $(\cdots)$, influent $\mathrm{pH}$ at $6.0(-)$ and effluent $\mathrm{pH}(\bullet)$. The SBR L was operated at constant 8 h.cycle ${ }^{-1}$ and the SBR H was operated in three periods (I: 8 h.cycle ${ }^{-1}$ SBR; II: batch for 6 days; and III: 8 h.cycle ${ }^{-1}$ SBR)

Figure 3. Profiles of the SBR under transient feeding conditions at low concentrations of electron donor and acceptor, SBR L1 (A1-3), SBR L2 (B1-3) and SBR L3 (C1-C3). A1), B1) and C1) Sulphur profiles: ${\mathrm{S}-\mathrm{SO}_{4}}^{2-}$ loading rate $(\cdots), \mathrm{S}_{-} \mathrm{SO}_{4}{ }^{2-}$ removal rate $(\diamond)$, production rate of $\mathrm{S}-\mathrm{S}^{2-}$ $(\diamond)$ and sulphate removal efficiency $(\times)$. A2), B2) and C2) COD profiles: the COD loading rate $(\cdots)$, COD removal rate $(\bullet)$, the lactate removal rate $(\bullet)$ and COD fraction as VFA in the

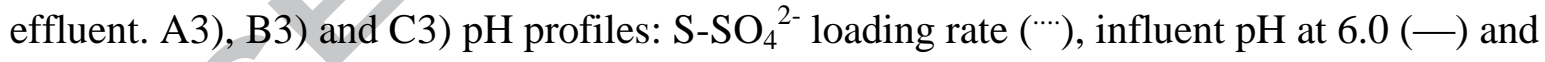
effluent $\mathrm{pH}(\bullet)$

Figure 4. Profiles of the SBR under transient feeding conditions at high concentrations of electron donor and acceptor, SBR H1 (A1-3), SBR H2 (B1-3) and SBR H3 (C1-3). A1), B1) and C1) Sulphur profiles: $\mathrm{S}_{-} \mathrm{SO}_{4}{ }^{2-}$ loading rate $(\cdots), \mathrm{S}_{-} \mathrm{SO}_{4}{ }^{2-}$ removal rate $(\bullet)$, production rate of S-S $(\diamond)$ and sulphate removal efficiency $(\times)$. A2), B2) and C2) COD profiles: the COD loading rate $(\cdots)$, COD removal rate $(\bullet)$, the lactate removal rate $(\bullet)$ and COD fraction as VFA in the

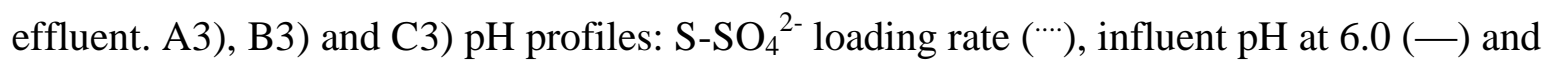
effluent $\mathrm{pH}(\bullet)$ 
Figure 5. The effect of electron donor and $\mathrm{NH}_{4}{ }^{+}$feast and famine conditions on sulphate reduction in batch bioreactors: A) Volumetric sulphate removal rate and the best fraction of sulphate removed against the initial sulphate concentration, B) Specific sulphate removal rate against the sulphate removed on the TCOD removed, C) Specific COD $_{\text {Lactate }}$ removal rate and fraction of lactate removed (after $8 \mathrm{~h}$ of operation) as function of the initial sulphate concentration, and D) Specific TCOD removal rate and fraction of TCOD removed (at the end of the sulphate reduction process) as a function of the initial sulphate concentration. In the primary axis: $\mathrm{NH}_{4}{ }^{+}$feast $(\diamond)$ and famine $(\boldsymbol{\square})$ conditions. In the secondary axis: $\mathrm{NH}_{4}{ }^{+}$feast $(\diamond)$ and famine ( $\square$ ) conditions 
A)

$\mathrm{L}$
Start up and biomass enrichment
$\mathrm{VSS}=8.9 \mathrm{~g} \cdot \mathrm{L}^{-1}$
$\mathrm{COD}=1 \mathrm{~g} \cdot \mathrm{L}^{-1}$
$\mathrm{SO}_{4}{ }^{2-}=0.4 \mathrm{~g} \cdot \mathrm{L}^{-1}$
$\mathrm{SO}_{4}{ }^{2-}: \mathrm{VSS}=0.045$
$\mathrm{COD}: \mathrm{SO}_{4}{ }^{2-}=2.4$
$\mathrm{NH}_{4}{ }^{+}=0.1 \mathrm{~g} \cdot \mathrm{L}^{-1}$

\section{B)}

L1

Control reactor

VSS $=7.7 \mathrm{~g} . \mathrm{L}^{-1}$

$\mathrm{COD}=1 \mathrm{~g} \cdot \mathrm{L}^{-1}$

$\mathrm{SO}_{4}{ }^{2-}=0.4 \mathrm{~g} \cdot \mathrm{L}^{-1}$

$\mathrm{SO}_{4}{ }^{2-}: \mathrm{VSS}=0.054$

$\mathrm{COD}: \mathrm{SO}_{4}{ }^{2-}=2.4$

$\mathrm{NH}_{4}{ }^{+}=0.1 \mathrm{~g} \cdot \mathrm{L}^{-1}$

D)

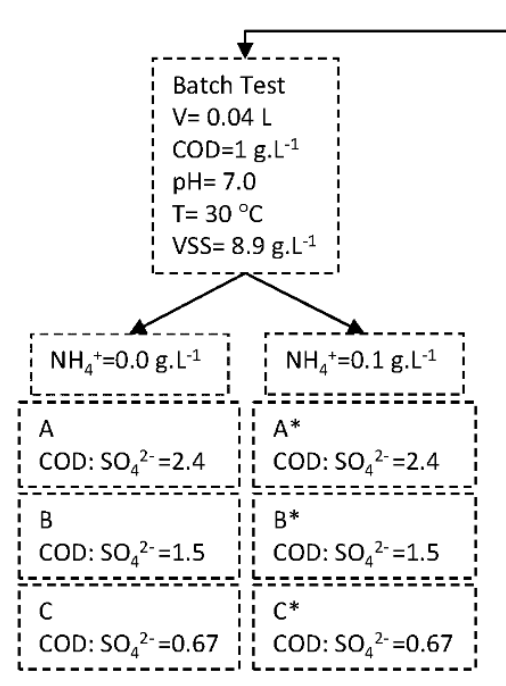

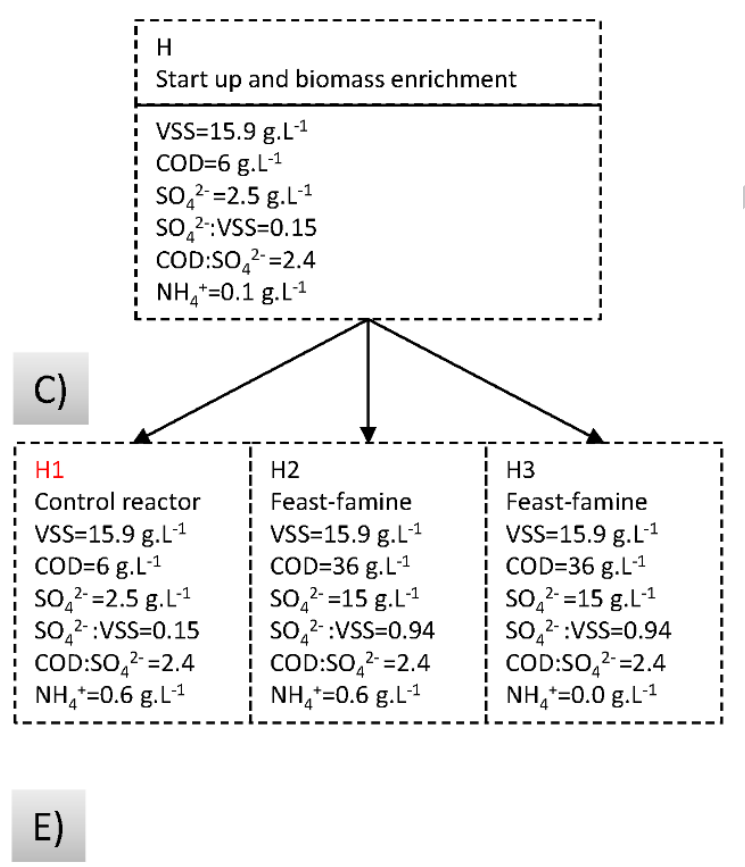

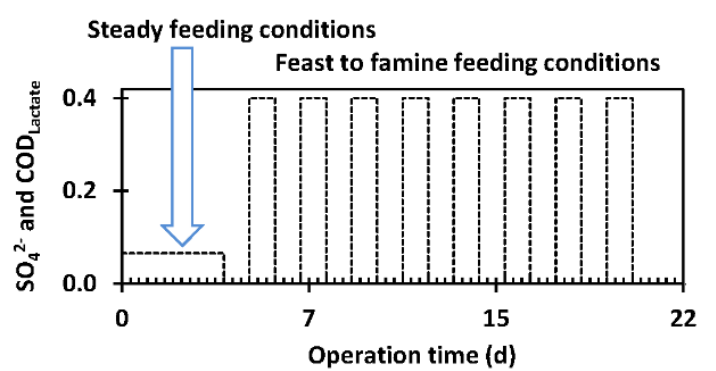

Figure

6. 


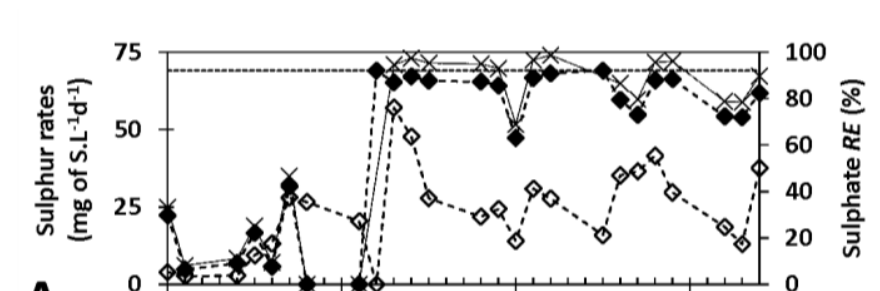

A
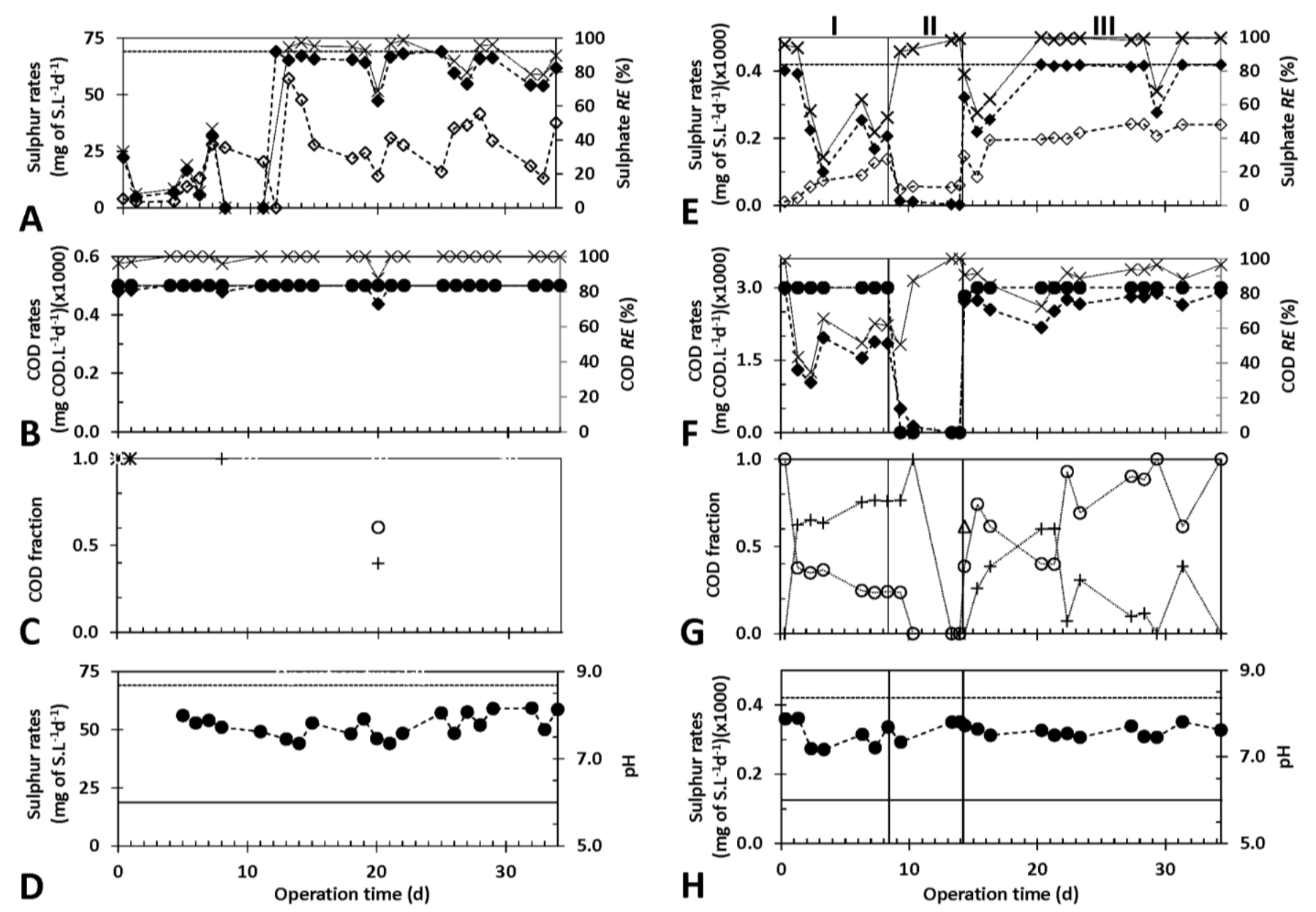

Figure 7. 


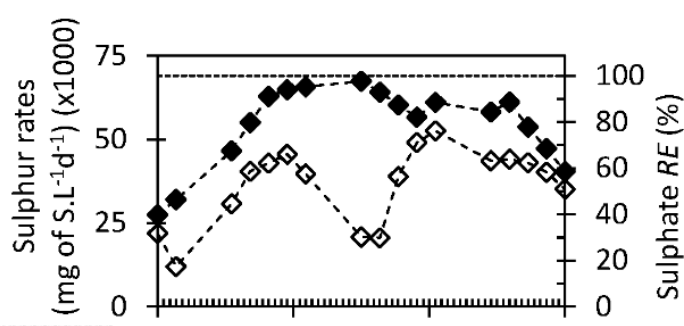

A1

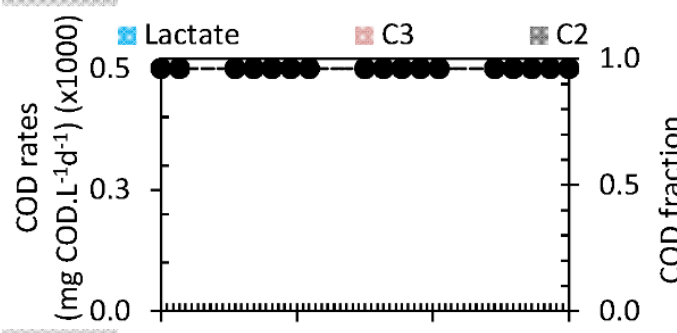

A2

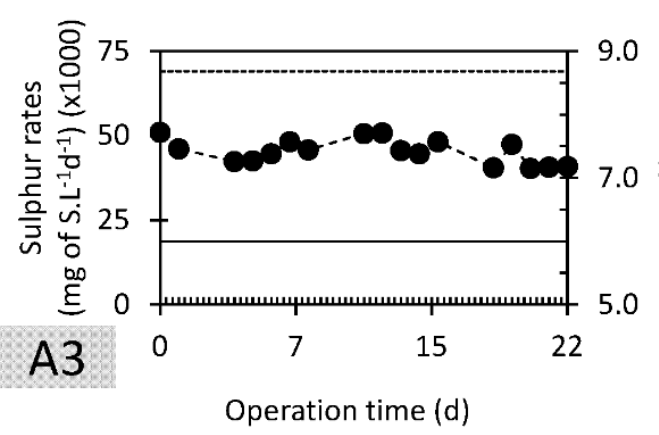

Figure 8 .

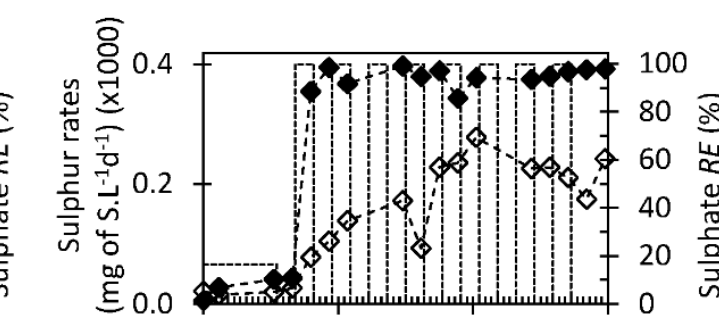

B1

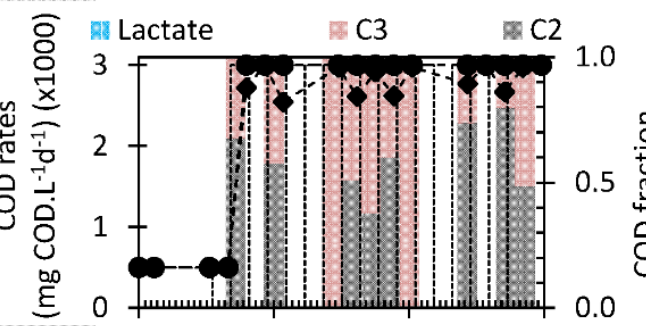

B2

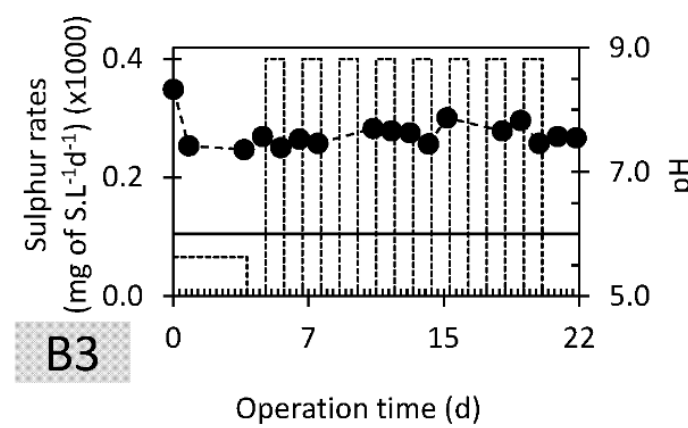

Operation time (d)

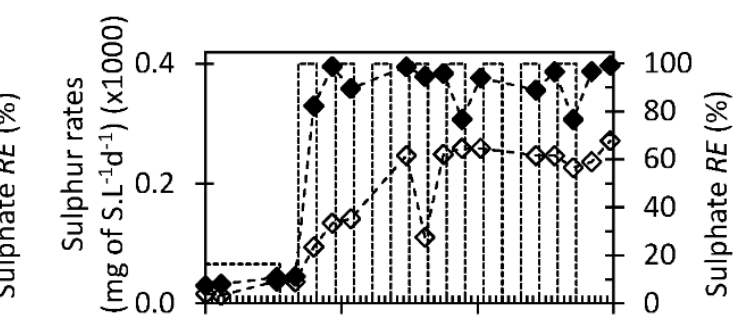

C1

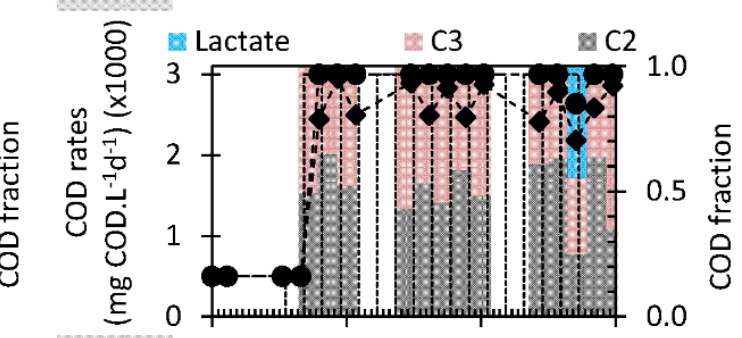

$\mathrm{C} 2$

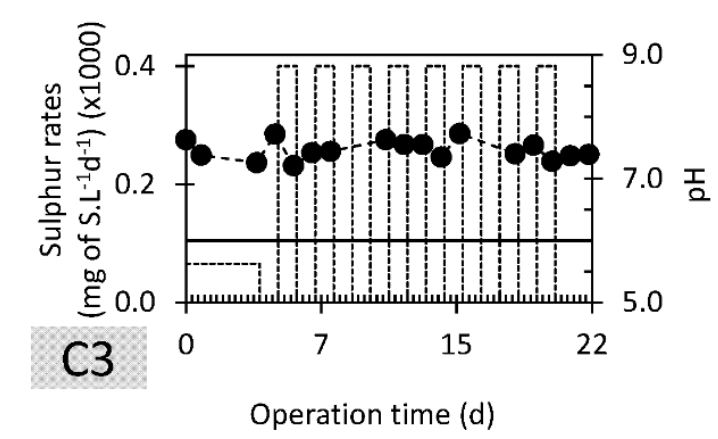




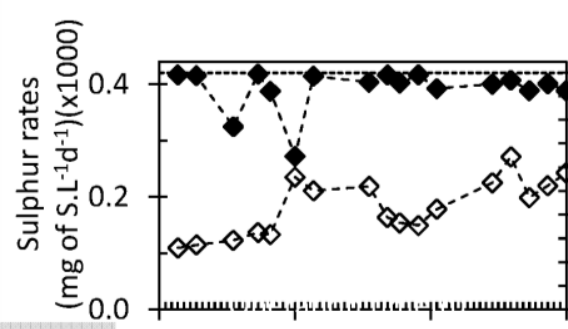

A1

lactate $\quad \square$ C3 $\quad$ C2

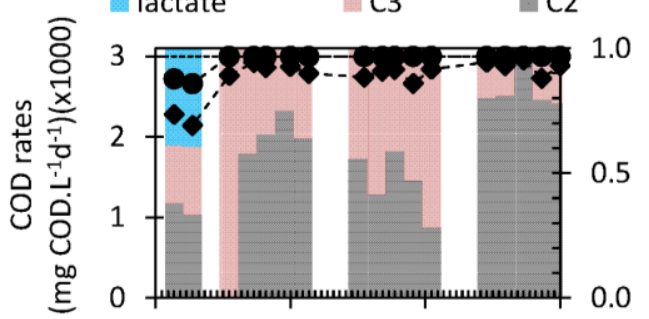

A2

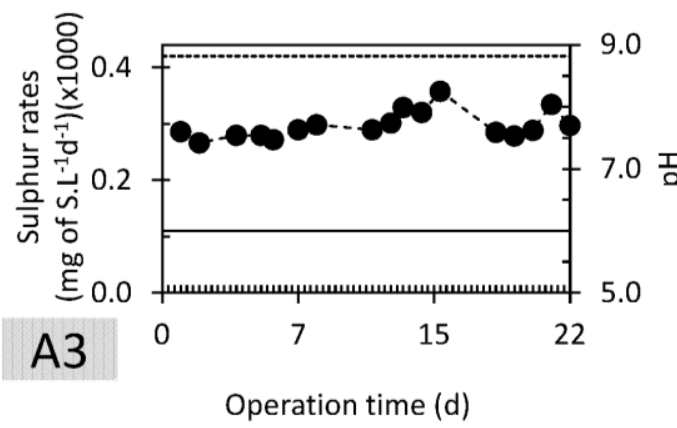

Operation time (d)

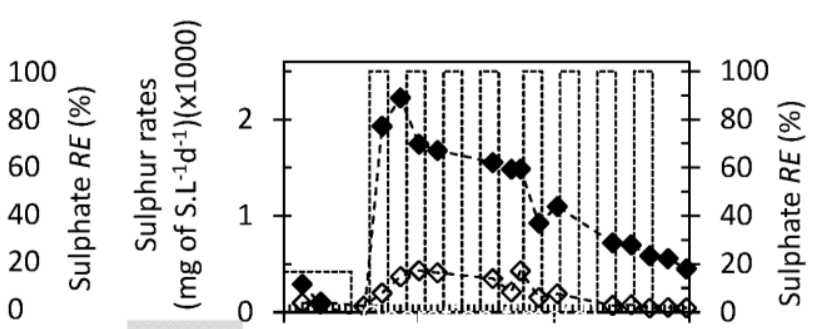

B1

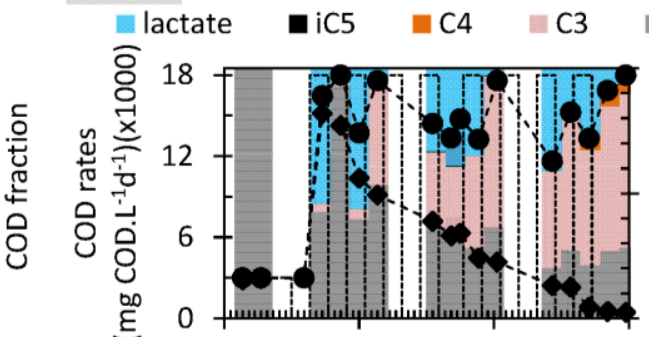

B2

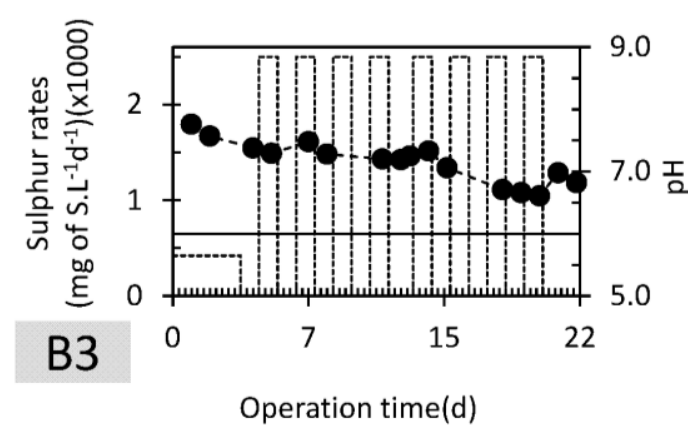

Operation time(d)

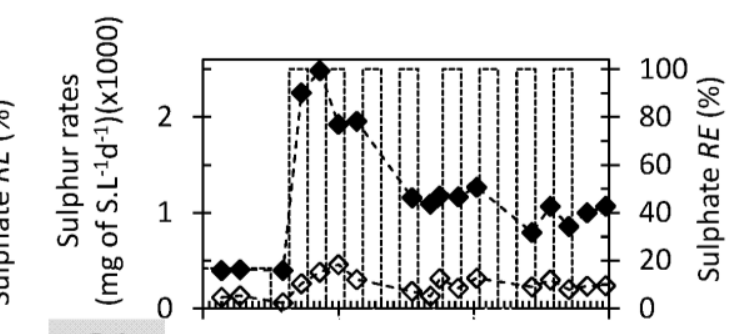

C1

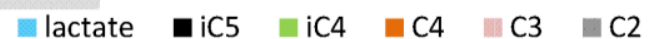

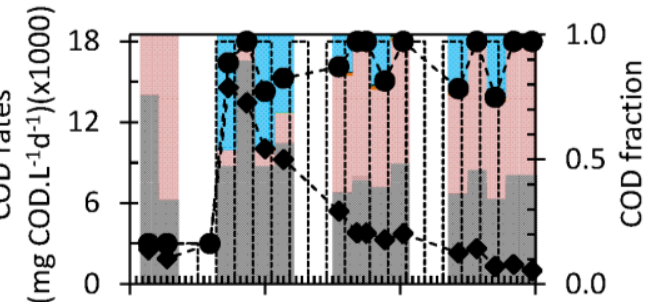

C2

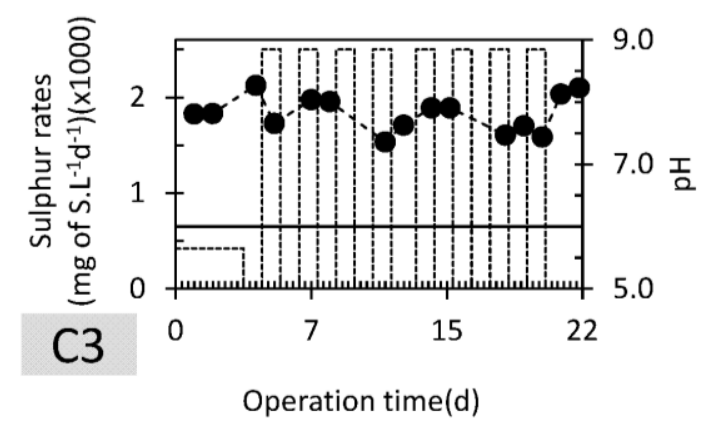

Figure 9. 

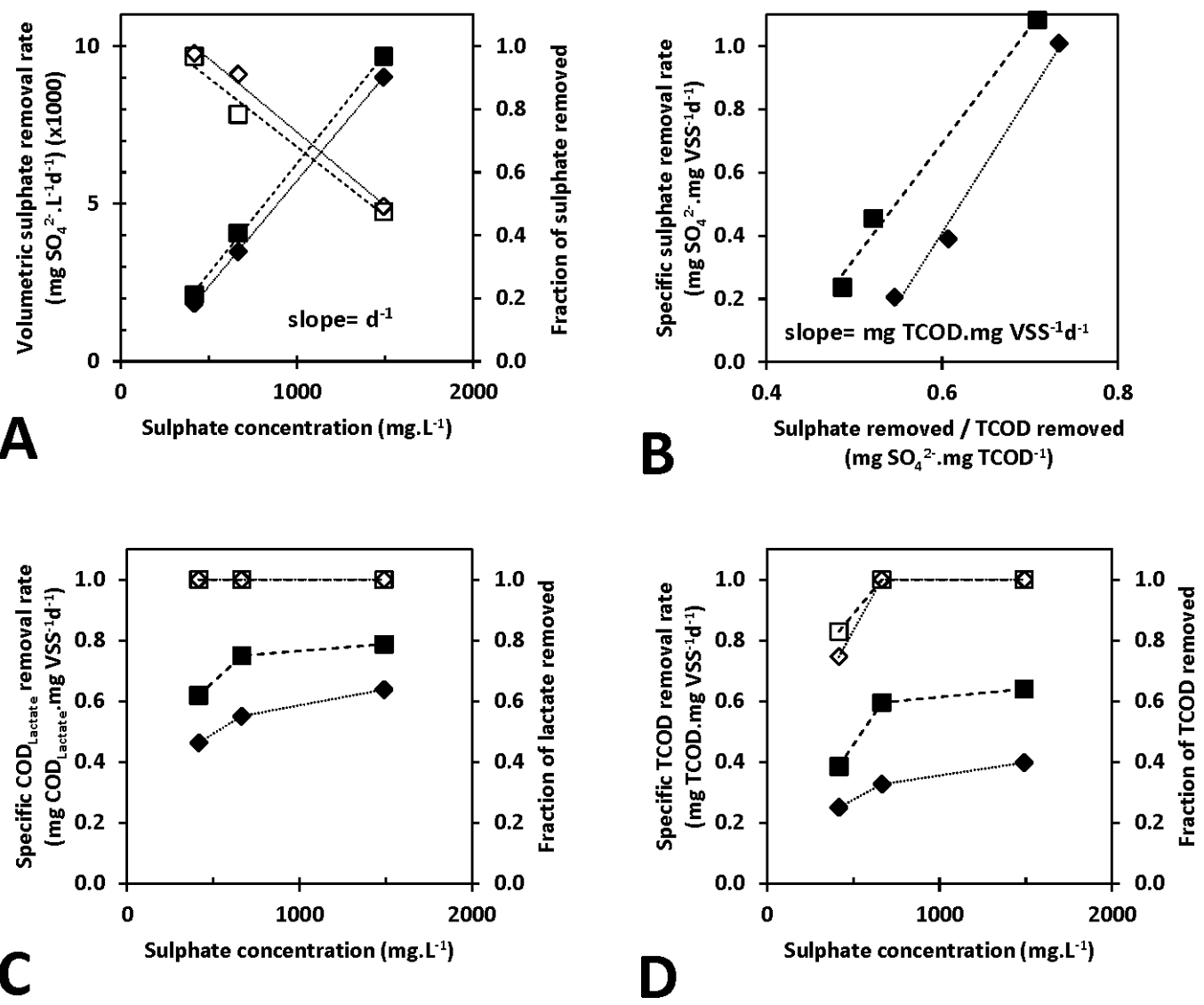

Figure 10. 
Table 1. Operational conditions and performance of the control (L) and experimental (H) SBR

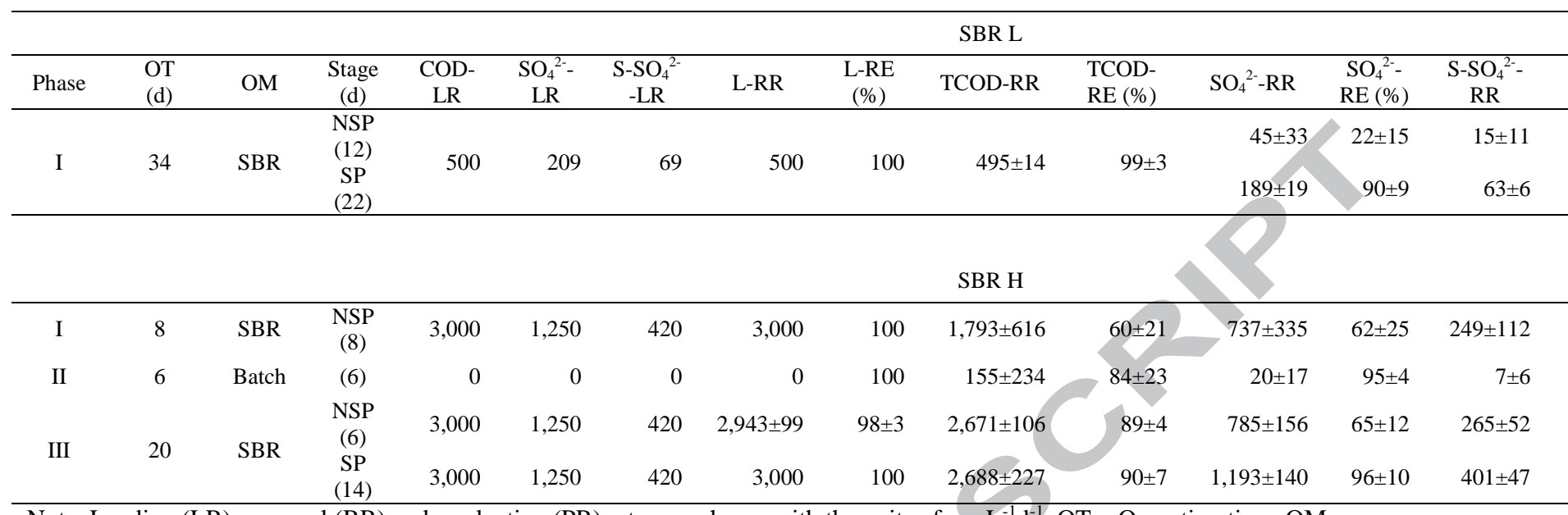

Note: Loading (LR), removal (RR) and production (PR) rates are shown with the units of $\mathrm{mg} \cdot \mathrm{L}^{-1} \mathrm{~d}^{-1}$. OT $=$ Operation time, OM $=$

Operation mode, NSP = non steady performance, $\mathrm{SP}=$ steady performance 
Table 2. Feast to famine initial conditions and parameters used for kinetic evaluation of sulphate reduction in batch experiments

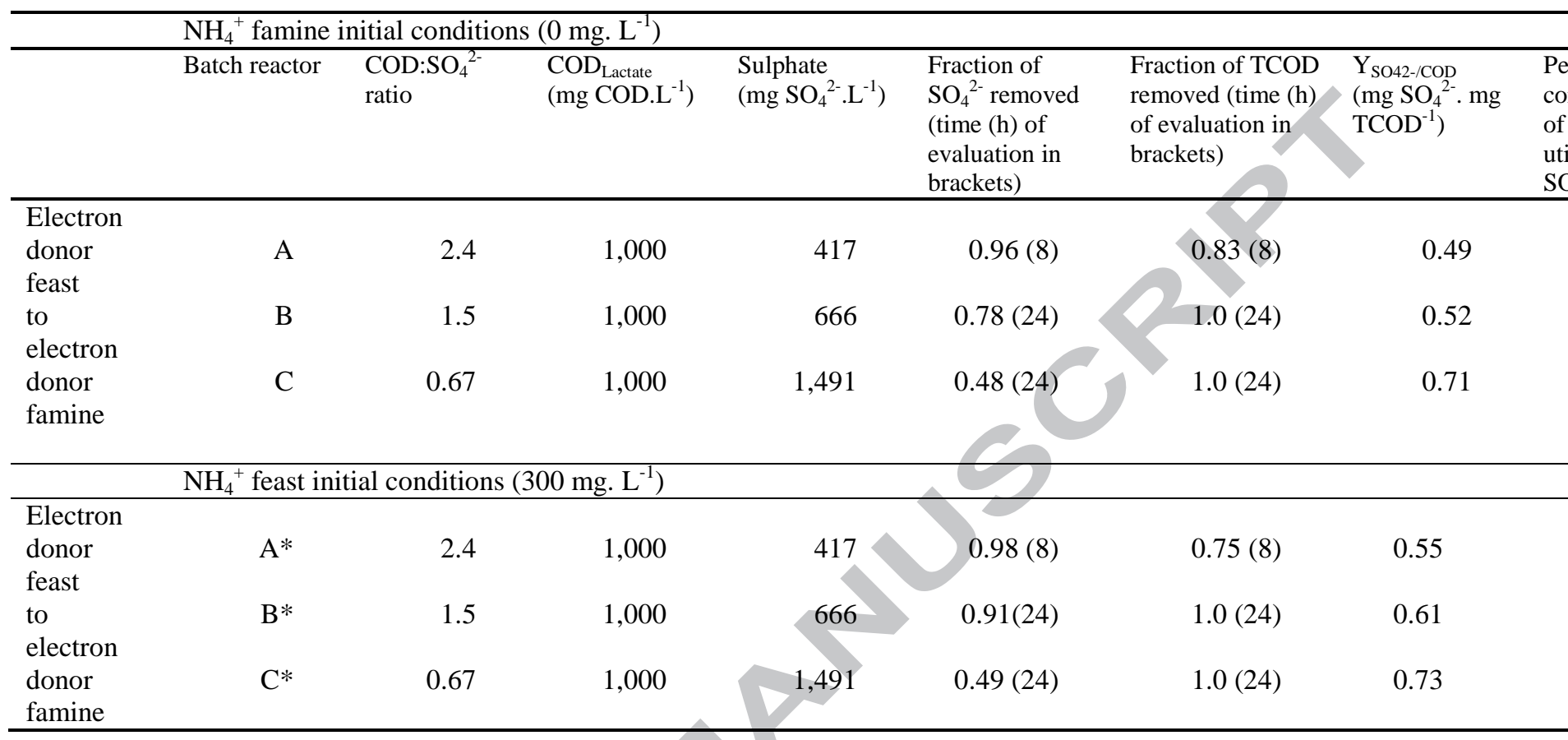


Effect of ammonium, electron donor and sulphate transient feeding conditions on

sulphidogenesis in sequencing batch bioreactors

\section{Graphical abstract}
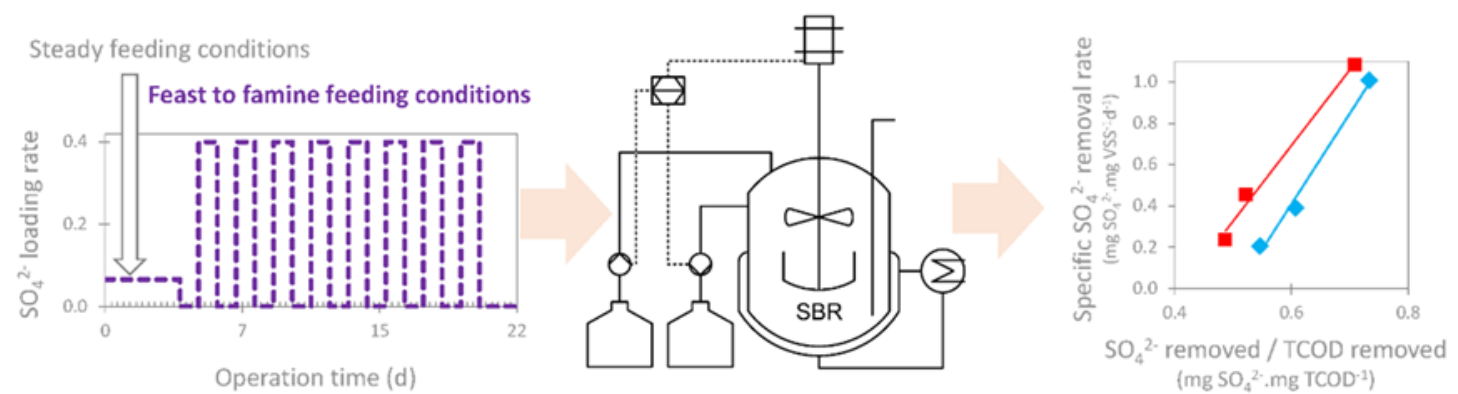
Effect of ammonium, electron donor and sulphate transient feeding conditions on sulphidogenesis in sequencing batch bioreactors

\section{Highlights}

- Sulphidogenesis was optimal at $2.5 \mathrm{~g} \mathrm{SO}_{4}{ }^{2-} \cdot \mathrm{L}^{-1}$ and a COD:sulphate ratio of 2.4

- Sulphidogenesis was robust to transient feeding conditions at $2.5 \mathrm{~g} \mathrm{SO}_{4}{ }^{2-} \cdot \mathrm{L}^{-1}$

- $\quad$ Sulphate $R E$ was $\geq 40 \%$ at $15 \mathrm{~g} \mathrm{SO}_{4}{ }^{2-} \cdot \mathrm{L}^{-1}$ influent sulphate concentration

- $\mathrm{NH}_{4}{ }^{+}$feast-famine conditions affected the sulphate reduction process 